\title{
On the power of indicators: how the choice of fuel poverty indicator affects the identification of the target population
}

\author{
Fizaine Florian ${ }^{1}$, Kahouli Sondès ${ }^{2,}{ }^{\text {* }}$
}

${ }^{1}$ Univ Savoie Mt Blanc, IREGE, Annecy Le Vieux, France.

${ }^{2}$ Univ Bretagne Occidentale, IFREMER, CNRS, Brest 3, France.

* Corresponding author : Sondès Kahouli, email address : sondes.kahouli@univ-brest.fr

\begin{abstract}
:
In light of the creation of the EU Energy Poverty Observatory (EPOV) in January 2018 and the increase in debates on how fuel poverty is measured, we propose a critical analysis of fuel poverty indicators and demonstrate that choosing a given indicator is central to the identification of the fuel-poorpopulation.

First, we conducted an inter-indicator analysis to show how profiles of fuel-poor households vary depending on the indicator selected. We designed a multidimensional approach based on a multiple correspondence analysis and a hierarchical and partitioning clustering analysis to study characteristics of fuel-poor households. We highlight the difficulty of identifying a fuel-poor 'typical profile' and show that the composition of the population depends on the choice of the indicator.

Second, we applied an intra-indicator analysis using two objective expenditure-based indicators with thresholds. In particular, we conducted a sensitivity analysis based on a logit model including variables describing household and dwelling characteristics. We show that the profiles of fuel-poor households as well as the drivers of fuel poverty vary considerably with the chosen threshold level.Given these findings, we stress the need to review how we currently rely on conventional fuel poverty indicators to identify target groups and give some recommendations.
\end{abstract}

Keywords: Fuel poverty, group identification, indicator dismantling, multidimensional analysis, sensitivity analysis

JEL CLASSIFICATION : C20, C38, Q40, Q48 


\section{Introduction}

Fuel poverty refers to a multidimensional concept that considers three main factors, namely the household financial situation, dwelling characteristics, i.e. energy efficiency, and energy prices (EPEE (2006), Devalière (2007), Palmer et al. (2008), Blavier et al. (2011)). A household is fuelpoor when it lives in an energy inefficient dwelling and is unable to heat its home at an appropriate standard level of warmth 3 due to insufficient financial resources.

Despite the spread of fuel poverty in Europe and its recognition by governments as a social, public health and environmental policy issue in an context of ever-increasing energy prices, and despite the recent creation of the EU Energy Poverty Observatory (EPOV) on 29 January 2018, the European Union (EU) has not yet adopted a common definition of fuel poverty, nor common indicators to measure it.

The UK government was the first to acknowledge the phenomenon and set up measures to fight it. In fact, the fuel poverty concept was born in the UK in the 1970s under the leadership of activist organizations who called the issue to the attention of authorities and the general population in light of the winter mortality induced by the steady rise in energy prices preventing some households from heating their dwellings at an appropriate standard level of warmth (Dutreix et al. (2014), ONPE (2014), ONPE (2015)). Two decades later, Boardman (1991) based on an earlier contribution by Isherwood and Hancock (1979) defined an indicator that has since been used in the 2001 UK Fuel Poverty Strategy to measure fuel poverty ${ }^{4}$

In France, the official definition of fuel poverty was published in the National Environmental Commitment Act (no. 2010-788 of 12 July 2010, "Loi Grenelle 2") amending the Housing Rights Act (no. 90-449 of 31 May 31 1990, "Loi Besson") 5. According to this definition, a fuel-poor household represents a person who has difficulties accessing energy inside his/her dwelling to satisfy his/her basic needs due to insufficient financial resources or inadequate dwelling characteristics i.e. energy inefficiency, presence of dampness and rot. Although it provided an official general framework for defining the fuel-poor, the French definition of fuel poverty remains impractical. In particular, it does not establish any clear-cut operational criteria to ensure the reliable identification of fuel-poor households and, therefore, appropriate implementation of policies to fight fuel poverty (Host et al. 2014). Recently, inspired by developments in the UK, the French National Observatory on Fuel Poverty ("Observatoire National de la Pauvrete Energetique"(ONPE)) uses various objective and subjective indicators to measure the magnitude of fuel poverty (( $\mathrm{ONPE}, 2014),(\mathrm{ONPE}, 2015))$.

Along the same lines, with the goal of combatting the problem, the French government passed the Energy Transition for Green Growth Act on 17 August 2015, which contains a social component calling for the prevention of fuel poverty by implementing short- and long-term policies. In particular, it set up curative measures to help fuel-poor households to pay their energy bills,

3. According to the World Health Organization (WHO), an appropriate standard level of warmth is equal to $21^{\circ} \mathrm{C}$ for the main living area and $18^{\circ} \mathrm{C}$ for other occupied rooms (ONPE 2015).

4. According to Fahmy et al. (2011), "the Warm Homes and Energy Conservation Act, effective from November 2000 and introduced with cross-party support, represents the first formal acknowledgement of fuel poverty as a social policy issue requiring governmental intervention. This act mandated the UK Government and Devolved Administrations to develop and implement a strategy for fuel poverty reduction, resulting in the 2001 UK Fuel Poverty Strategy. This official document committed the UK Government and Devolved Administrations for the first time to the ambitious goal of eliminating fuel poverty (DETR, 2001). Fuel poverty reduction targets include eliminating fuel poverty in England amongst "vulnerable" households by 2010, i.e. older persons, sick and disabled households and families with children, and amongst all households by 2016. These targets were reaffirmed in the 2007 Energy White Paper DTI (2007), and broadly similar targets are in place within the Devolved Administrations (DSDNI (2004), Scottish Executive (2002), WAG (2003))".

5. La "Loi Besson" no. 90-449 of 31 May 1990 stipulates that anyone encountering difficulties, particularly due to insufficient financial resources or inadequate living conditions, can benefit from the support of the community, according to the rules stipulated in the Act, to have access to decent and independent housing ensuring water, energy and telephone access - Translated from French (JORF, 1990). 
i.e. income support, affordable fuel pricing and assistance with solvency in the case of arrears, and preventive policies that focus on the improvement of dwelling energy efficiency, i.e. dwelling insulation, double glazing, etc.

Prior to discussions on the effectiveness of these different policies, debates focused on the key issue of reliably identifying fuel-poor households and describing their profiles. Within these debates is the question of the relevance of fuel-poverty indicators used to identify the affected population. The extent of the problem, the composition of groups and, therefore, the implementation of suitable public policies depend strongly on the types of indicator used to identify the fuel-poor and on their construction.

In addition to discussing drawbacks of conventional indicators, one recurrent question deals with the choice of the type of indicator to use to identify fuel-poor households: energy expenditure-based indicators with thresholds, subjective self-reported indicators or consensual social indicators? In a recent study, Heindl and Schuessler (2015) showed that most energy expenditure-based indicators show odd dynamic behaviour in micro-simulations, and can thus lead to misleading or contradictory conclusions on population identification. Considering the same type of expenditure-based indicators, Hills (2012) previously argued that their construction can make them overly sensitive to energy prices, and thus to a misidentification of the fuel-poor population. Similarly, because most expenditure-based indicators are based on the definition of energy expenditures and/or income thresholds, several criticisms based on discursive analyses have focused on the main impacts of the choice of the type of threshold on the identification process 6 . Although some authors argue for the use of an absolute threshold as in the case of the $10 \%$ indicator, others support the use of relative thresholds based on means or medians of expenditures (Moore (2012), Boardman (2012), Liddell et al. (2012)). Regardless of the type of threshold, the choice of the level to apply often lacks theoretical foundation (Boardman, 2012). For example, the $10 \%$ threshold was set by doubling the median energy expenditures based on the 1988 Family Expenditure Survey for UK households, which has not been updated since. Beyond the question of the threshold, some other criticisms focus on the choice of statistics used to build the indicators, for example the type of income, i.e. full income, residual income, equivalised income and the type of energy expenditures, i.e. actual and theoretical, estimated expenditures (Moore (2012), Heindl (2013)). Finally, other studies have highlighted the need to fundamentally review how indicators are defined to account for the multidimensional nature of fuel poverty, which complicates the identification process. Fuel poverty cannot be reduced to a solely monetary dimension, neglecting other important related issues such as general deprivation (poverty), health, social exclusion and even environmental concerns.

A critical review of the literature on fuel poverty indicators raises two important issues. First, because fuel poverty indicators have neither real theoretical foundations nor reached an empirical consensus as to the identification of fuel-poor households, the use of one indicator rather than another may prevent some affected households from being targeted by public policy measures devoted to eliminating the problem. Therefore, it is important to identify the trade-offs of each indicator and how the indicators are applied. Second, the profiles of the fuel-poor may or may not be homogeneous; it is important to determine how homogeneity can affect implementation, reliability and the relevance of public policies targeting fuel poverty. To address these two issues, we analyse in detail the impact of the choice of the fuel poverty indicator on the identification of fuel-poor households, in particular, on the description of their profile. Our aim is to lend empirical support to the discursive criticisms of current fuel-poverty indicators that highlight the influential trade-offs operating during the design and monitoring stages of economic policies devoted to fight-

6. As far as we know, no quantitative analyses or empirical applications have been carried out in support of these criticisms. 
ing fuel poverty. Moreover, within the framework of the recent creation of the EPOV, our aim is to shed light on the importance of formulating an official European definition of fuel poverty based on which either common or national indicators could be defined. This may, among others, "improve transparency by bringing together the disparate sources of data and knowledge that exist in varying degrees across the whole of the EU" and "promote informed decision making by local, national and EU-level decision makers', 7

By using an original French database, named "Phébus" ( $c f$. section 3 for more details), developed to study the fuel poverty issue in France, we demonstrate the variability in the profiles of fuel-poor households across indicators and how their threshold level is constructed. The composition of fuel-poor households, and thus their characteristics, depend on which indicators is used.

The paper is structured as follows. In Section 2, we critically review existing fuel poverty indicators. We distinguish three groups of indicators: objective factual indicators, subjective selfreported indicators and composite indices. We detail their respective advantages and drawbacks. In Section 3, we analyse how profiles of fuel-poor households vary across indicators and with the indicator threshold. In particular, in Sub-section 3.1 we identify affected households using a set of conventional objective and subjective indicators and we propose a multidimensional qualitative approach based on multiple correspondence analysis (MCA) and a hierarchical and partitioning clustering (HPC) method to analyse their characteristics ${ }^{8}$. Within this framework, we highlight the difficulty of identifying a "typical profile" of a fuel-poor household due to the variability in their profiles and show that the composition of the fuel-poor population depends on the choice of the indicator. In Sub-section 3.2. based on two objective fuel poverty indicators, we conduct an innovative sensitivity analysis using a logit model including variables describing household and dwelling characteristics to demonstrate the limits of using exogenous indicator thresholds to determine groups of fuel-poor households. Likewise, by considering the case of the French Energy Voucher policy adopted as of January 2018 as a tool to fight fuel poverty and by using a sensitivity analysis, we study how the target fuel-poor households vary depending on the policy threshold currently aimed at the poorest $15 \%$ of households. We find that profiles of fuel-poor households, as well as drivers of fuel poverty, vary considerably depending on the chosen threshold level. In Section 4 , we discuss our results and give some recommendations. Finally, in Section 5 , we draw some conclusions.

\section{Critical review of fuel poverty indicators}

In this section, we briefly present and discuss the advantages and drawbacks of fuel poverty indicators that divide the general population into homogeneous groups. Figure 1 and Appendix A summarise the content of this section.

\subsection{Objective factual indicators}

Objective factual indicators of fuel poverty are based on measurable and observable criteria. We distinguish between expenditure-based indicators, the restriction-behaviour approach and consensual social indicators.

7. Source: https://www.energypoverty.eu/about/role-and-mission

8. Although our goals differ, Hache et al. (2017) is, as far as we know, the only study that has used a clustering analysis based on CHAID methodology to separate French household energy consumption into several homogeneous groups with regard to fuel poverty by relying on pre-identified predictors from the literature. Although that study offered a useful description of profiles of fuel-poor households, it still suffers from the criticisms that we address in this study with regard to identification of the fuel-poor. 
Expenditure-based indicators draw on notions from consumption economics. In particular, they take into account the amount of expenditures devoted to satisfy fuel needs with respect to the total available financial endowments. We examine here the 10\% indicator (Boardman (1991)), the after-fuel-costs poverty (AFCP) indicator (Hills (2011)) and the low-income/high-costs (LIHC) indicator (Hills $(2011,2012))$.

- The $10 \%$ indicator

The $10 \%$ indicator, also called the fuel poverty (FP) ratio, is calculated as follows:

$$
\begin{aligned}
\text { The } 10 \% \text { indicator } & =\frac{\text { Theoretical fuel costs }}{\text { Equalised disposable income }} \\
& =\frac{(\text { Theoretical fuel consumption } \times \text { fuel price })}{\text { Equalised disposable income }}
\end{aligned}
$$

A household is considered fuel-poor if it spends more than $10 \%$ of its equivalised disposable income (before housing costs) on fuel supply to maintain an appropriate standard level of warmth inside its dwelling 9 The equivalised disposable income is the total income of a household, after taxes and other deductions, that is available for spending or saving, divided by the number of household members converted into equivalised adults, i.e. number of consumption units $(c u)$. Household members are equivalised or made equivalent by weighting each according to their age using an official equivalence scale.

The $10 \%$ indicator considers theoretical rather than actual/observed fuel costs. These costs are modelled by multiplying fuel requirements by fuel prices. These requirements are calculated based on a number of factors including primarily the size of the dwelling, the number of people who live in it, its energy efficiency level and the fuels used. In addition, theoretical fuel costs capture four areas of fuel consumption, namely space heating, water heating, lights and appliances and cooking needs (DECC, 2014). Typically, the majority of the fuel bill goes towards space heating 10 It is generally difficult to calculate theoretical fuel costs. Therefore, an alternative widespread way to determine the $10 \%$ indicator is to use actual/observed fuel costs.

Although this indicator has the advantage of taking into account under-consumption by comparing theoretical and actual fuel consumption, it is not intended to measure whether households are spending more than $10 \%$ of their income on domestic fuel, but rather whether they would need to do so to reach an acceptable warmth level in their dwelling on the basis of observed income and modelled physical data related to dwelling space and thermal efficiency (Fahmy et al. (2011), Legendre and Ricci (2015)). Moreover, when based on actual fuel costs, the $10 \%$ indicator does not take into account the restriction or deprivation practices of some households, i.e. under-heating with regard to heating needs, induced by high fuel costs (Dutreix et al., 2014).

Using the same criticism, Hills (2011) and Moore (2012) argue that the $10 \%$ indicator does not reliably take into account the income level, particularly in the case of households with high income. In effect, in essence, when used to determine the extent of fuel poverty, the $10 \%$ indicator does not include a cut-off for households with high income. Therefore, a

9. $C f$. footnote number 3 for an official definition of an appropriate level of warmth.

10. In the UK in 2013, on average, around $51 \%$ of the theoretical household bill was devoted to space heating, $34 \%$ for lighting and appliances usage, $12 \%$ for water heating and $3 \%$ for cooking (DECC, 2014). 


\section{— The low-income/high-costs (LIHC) indicator}

Defined by Hills (2011, 2012), the LIHC indicator considers two thresholds to identify fuelpoor households. The first is the household equivalised disposal income that should be less than $60 \%$ of the equivalised national median disposal income. The latter is equal to the equivalised income net of housing and domestic fuel costs 11 . The second threshold defines a standard level of fuel expenditures. In particular, the household equivalised fuel expenditures should be equal to or greater than the required national median fuel expenditures. Therefore, according to this approach, a household is fuel-poor if:

$$
\left\{\begin{array}{l}
\text { Equalised net income } \leqslant 60 \% \text { (Equalised median net income) } \\
\text { and } \\
\text { Equalised fuel expenditures } \geqslant \text { Required national median fuel expenditures }
\end{array}\right.
$$

We distinguish between the LIHC $\left(m^{2}\right)$ and $(c u)$. The LIHC $\left(m^{2}\right)$ indicator equalises fuel

11. Therefore, this income threshold corresponds to the definition of the AFCP indicator. 
expenditures by dividing them by the surface area of the dwelling in square meters $\left(\mathrm{m}^{2}\right)$, whereas the LIHC $(c u)$ indicator equalises fuel expenditures by dividing them by the number of consumption units $(c u)$ of the household. The LIHC is a dual indicator that measures not only the extent of fuel poverty (how many fuel-poor households there are) but also the depth of the problem (how badly affected each fuel-poor household is). The depth of fuel poverty is calculated by taking into account the fuel poverty gap, which is a measure of the additional fuel costs faced by fuel-poor households, to meet the non-fuel-poor household threshold.

With respect to the AFCP indicator, the advantage of the LIHC indicator is that it clearly distinguishes between fuel and monetary poverty by applying two different thresholds. However, as in the case of the AFCP indicator, the LIHC indicator is based on the calculation of the net income after housing and domestic fuel costs. Moreover, it does not take into account the heat-restriction behaviour of some households.

\section{The restriction-behavior indicator and consensual social indicators}

Indicators based on restriction behaviour stand out from other expenditure-based indicators, but still belong to the class of objective indicators. Restriction-behaviour indicators are based on the calculation of the actual and the theoretical fuel consumption necessary to reach an appropriate dwelling level of warmth ${ }^{12}$ and on the determination of the difference between them. When calculated, the theoretical fuel consumption takes into account the dwelling's energy efficiency.

In addition to quantifying restriction behaviour, this approach can also determine which households have a suitable cost analysis for performing dwelling retrofit energy investments (Charlier (2013, 2014)). The main difficulty encountered when calculating this indicator is the assessment of theoretical fuel consumption 13

Also belonging to the group of objective factual indicators and in addition to the expenditurebased and restriction-behaviour indicators, consensual social indicators are also used to assess the magnitude of fuel poverty. They are based on the monetary poverty and deprivation literature, which go beyond the observations exposed in the recently developed fuel poverty literature (Townsend (1979), Callan et al. (1993), Gordon et al. (2000)). These indicators stipulate that some goods and services are considered as necessary for a person to be able to conduct a socially dignified lifestyle. They are regarded as essential attributes and are perceived as socially necessary. Therefore, according to the consensual social approach, when considering the energy context, a deprivation state with regard to basic household utility needs is considered as an indicator of fuel poverty. In other words, the use of consensual social indicators aims to capture the wider elements of fuel poverty, namely energy poverty by focusing on social exclusion and material deprivation, as opposed to approaches based solely on expenditure-based indicators. The use of consensual social indicators relies on the combination of several dimension of energy poverty such as cooking, lighting, communication, education, etc.

\section{$2.2 \quad$ Subjective self-reported indicators}

Subjective fuel poverty indicators are based on personal opinions, interpretations, points of view and judgment. They are usually constructed by referring to households' self-reported answers

12. $c f$. footnote number 3 for a standard definition of an appropriate level of warmth.

13. Charlier 2013 2014) assessed theoretical fuel consumption using Promodul software by taking into account dwelling characteristics and by referring to the 3CL-DPE method presented in the French Energy Performance Diagnosis Act of September 2006 for existing buildings put up for sale in France (JORF 2006). 
on questions asked by social investigators during a survey. The most frequently asked questions include:

- Do you suffer from thermal discomfort?

- Have you had difficulty in paying your utility bills (in the past)?

- Can you afford your energy bills?

- Are you satisfied with your heating equipment?

Several studies use subjective indicators to study fuel poverty. For example, Healy (2003) considers three subjective indicators based on the questions listed above to analyse the fuel poverty in Ireland and the EU. Also, the INSEE ENL (2006) and EPEE (2006) analyses of fuel poverty are based on subjective indicators. In particular, EPEE (2006) defines fuel poverty as "the household's difficulty, sometimes even the inability, to adequately heat its dwelling at a fair price", and in the French dwelling survey (INSEE ENL (2006)), households are asked to answer the question "Did you suffer from the cold for at least 24 hours in your home last winter?". Within the same framework, Price et al. (2012), in exploring the links between objective and subjective indicators of fuel poverty in UK, use a subjective self-declared indicators of fuel poverty based on whether consumers feel able to afford their energy bills.

Since these subjective indicators are constructed on the basis of self-reported answers strongly correlated with different personal standards, results of different studies should be interpreted with caution mainly with respect to the identification of fuel-poor households. In particular, the interpretation of results may contradict those based on objective factual indicators, although the introduction of self-reported indicators provides valuable information in terms of identifying the fuel-poor and of policy development (Price et al., 2012).

\subsection{Composite indices}

Composite indices were created as a compromise between the simplicity of one-dimensional indicators and the need to account for the multidimensional nature of fuel poverty. They represent an attempt to overcome the shortcomings of one-dimensional indicators and, at the same time, produce a result that condenses the information into single and easy-to-interpret metrics (Thomson and Snell, 2013). Based on a set of sub-indicators, these indices aim to associate several attributes of fuel poverty that cannot be reliably depicted in a single indicator. Several attempts have been made to construct composite indices for developed countries for which the main focus is selecting which aspects of poverty to take into account, i.e. energy prices, income, dwelling energy efficiency, personal judgment (Thomson and Snell (2013), Fabbri (2015), Charlier and Legendre (2016), Okushima (2017)). Although these attempts make a significant contribution, there is still a room for improvement in the measurement of fuel poverty. For example, based on the more exhaustive conceptual framework of the energy poverty literature applied to developing countries, which focuses on the issue of access to energy rather than thermal discomfort as in developed countries, Nussbaumer et al. (2012) propose new multidimensional indicators to measure fuel poverty.

The main drawback of composite indices is that combining variables causes some form of information reduction or loss, with all the associated methodological issues and required assumptions and simplifications it implies (including value judgments). Therefore, if not meticulously handled, composite indices can be seriously misleading when identifying the fuel-poor and defining public policies. 


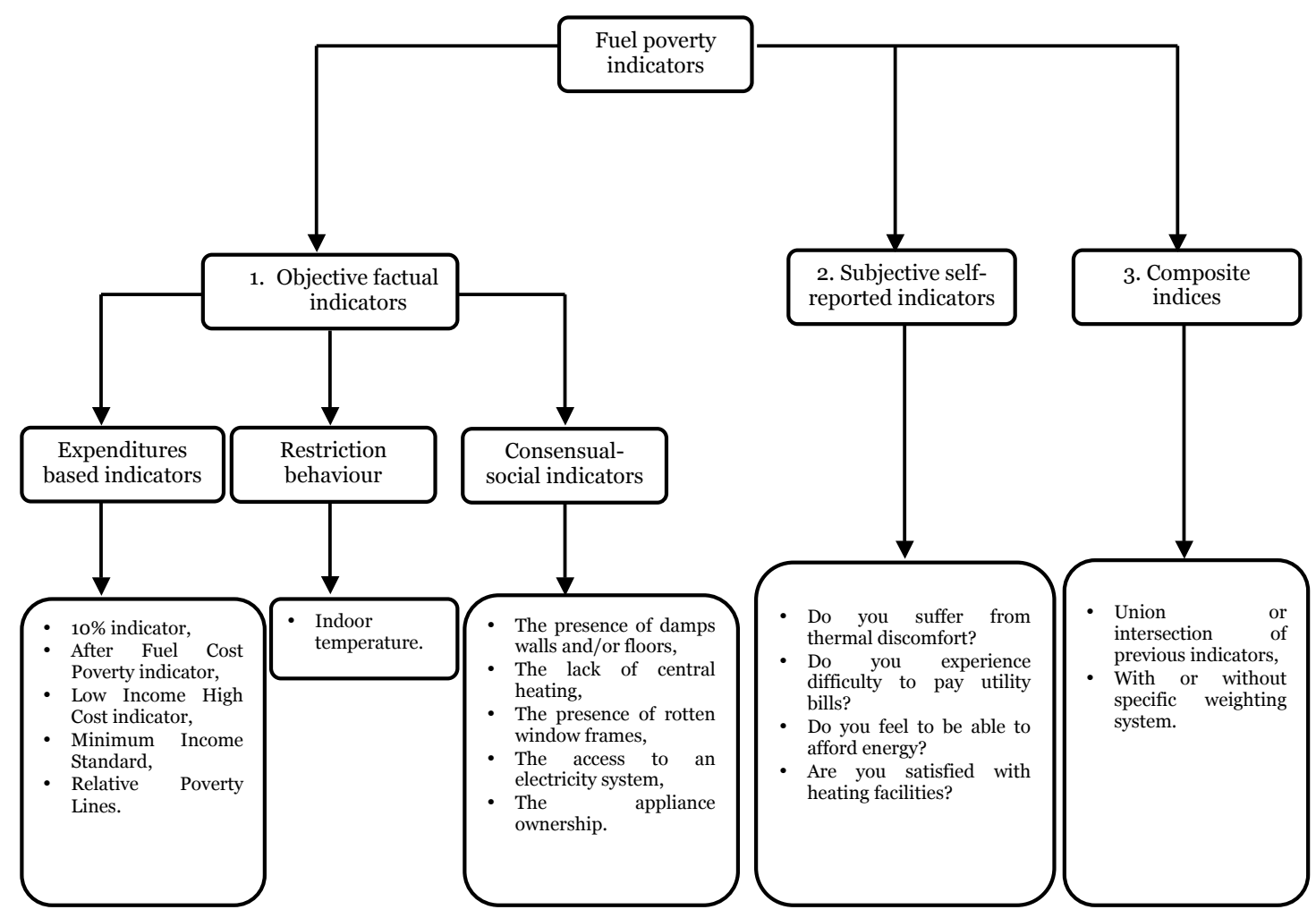

Figure 1. Summary of fuel poverty indicators. Source: authors elaboration.

\section{Which households are fuel-poor?}

In this section, we show how difficult it is to identify fuel-poor households.

To do so, we start by calculating fuel poverty rates, or equivalently, determining the population of fuel-poor households. We use data extracted from the "Phébus" database ("Performance de l'Habitat, Equipements, Besoins et Usages de l'énergie") which is especially devoted to the in-depth analysis of the fuel poverty issue in France. This database was compiled from April to October 2013 by the Ministry of Ecology, Sustainable Development and Energy ("Ministère de l'Ecologie, du Développement durable et de l'Energie" (MEDDE)), the General Commission for Sustainable Development ("Commissariat Général au Développement Durable" (CGDD)), and the Department of Observation and Statistics ("Service de l'observation et des statistiques" (SOeS)). It is divided into two parts: (1) a face-to-face interview with the occupants of the home about their energy consumption, expenditures and attitudes and (2) an energy efficiency diagnosis of the dwelling. In particular, "Phébus" contains information describing the household, i.e. the amount of energy expenditures, attitudes toward energy consumption, disposable income, age, etc., and dwelling characteristics, i.e. surface, type of heating system, level of energy efficiency, etc. Therefore, it can study the household's energy consumption in detail and the associated issue of fuel poverty. The "Phébus" database covers the year 2013.

We calculated fuel poverty rates for 2013 using two objective expenditure indicators, i.e. the $10 \%$ and the LIHC $\left(\mathrm{m}^{2}\right)$ indicators, and one subjective indicator, i.e. the Thermal Discomfort indicator. This indicator relies on the answer of households to the following question "Did you suffer from the cold in your dwelling for at least 24 hours last winter?"14.

14. We calculated the fuel poverty rate using the LIHC $(c u)$ indicator. Because results are quite similar to those of the LIHC $\left(\mathrm{m}^{2}\right)$, we do not report them here to save space. They are however available upon request. 
In Appendix B, we detail how we compute fuel poverty rates using the $10 \%, \mathrm{LIHC}\left(\mathrm{m}^{2}\right)$ and Thermal Discomfort indicators. Our initial data set was composed of 5405 households. Our results show that $14.16 \%$ (766), $10.95 \%$ (592), 9.52\% (514), and 7.75\% (419) of households are fuel-poor according to the $10 \%$, LIHC $\left(\mathrm{m}^{2}\right)$, LIHC $(\mathrm{cu})$, and Thermal Discomfort indicators, respectively.

Then, after identifying fuel-poor households, we focused in Sub-sections 3.1 and 3.2 below on the variability of the profiles. Therefore, we conducted inter-indicator and intra-indicator variability analyses. The inter-indicator variability indicates how profiles of fuel-poor households vary depending on the indicator used to identify fuel-poor population (Sub-section 3.1). The intraindicator variability deals with the construction of the indicator and means that when varying the threshold level of a given indicator ${ }^{15}$ profiles of fuel-poor households vary (Sub-section 3.2 )

\subsection{Inter-indicator analysis: how profiles of fuel-poor households vary across indicators}

To analyze how profiles of fuel-poor households vary across indicators, we used three complementary methods. The first is a multiple correspondence analysis (MCA), which is a variation on the principal component method. The second is the hierarchical clustering (HC) method. The third is the partitional clustering method (PC).

Principal component methods include three types of analyses:

- Principal component analysis (PCA), which is suitable for analyzing databases containing quantitative/continuous variables;

- Correspondence analysis (CA), which is used to handle a data set composed of two qualitative/categorical variables;

- Multiple correspondence analysis (MCA), which is an extension of simple CA used to analyse a database containing more than two categorical variables.

The core idea common to all principal component methods is to describe a dataset ( $X$ with $I$ individuals and $K$ variables) using a small number $(S<K)$ of uncorrelated variables that retain as much information as possible. The reduction in variables is achieved by transforming the data into a new set of continuous variables called principal components (Husson et al., 2016). One major advantage of principal component methods, in particular MCA, is that it can analyse the multidimensional character of a dataset as in the case of the fuel poverty issue. Therefore, we ran an MCA on each sample of fuel-poor households determined in the previous sub-section based on the (objective) 10\% and LIHC indicators and on (the subjective) Thermal Discomfort indicator ${ }^{16}$.

By extension, because PCA is considered as a pre-process for clustering 17 , we used our MCA results to perform hierarchical and partititional clustering (HPC). We sought to classify fuel-poor households with similar characteristics into homogeneous groups and compare the results (mainly) across indicators, although we can also analyse the variability of profiles for a given indicator. Hierarchical clustering was based on Ward's criterion. This criterion refers to Huygen's theorem, which decomposes the total inertia (total variance) into between- and within-group variance. More precisely, Ward's criterion consists in aggregating two clusters to minimise the growth of within-group

15. We focus here on the class of "expenditure-based indicators" where most indicators are based on the definition of a threshold ( $c f$. Section 2).

16. For the LIHC indicator, to save space, we present results only for LIHC $\left(m^{2}\right)$. Results for LIHC (cu), which corroborate our global results, are available upon request.

17. PCA can effectively be viewed as a "noise removal" method. The first dimension extracts the essential information and the subsequent dimensions are restricted to noise. Without noise in the data, clustering is more stable. 
inertia (in other words, minimising the reduction of the between-group inertia). The within-group inertia characterises the homogeneity of a cluster. The hierarchy is represented by a hierarchical tree, i.e. a dendrogram, which is indexed by the increase in within-group inertia (Husson et al., 2016). This hierarchical tree can be considered as a sequence of nested partitions, ranging from one in which each individual is a cluster to one in which all the individuals belong to the same cluster. The number of clusters can then be chosen looking at the overall appearance (or the shape) of the tree, alongside the bar plot of the increase in within-group inertia, etc. These rules are often based - implicitly or not - on the growth of inertia. Different strategies are available to define clusters (partitioning). The simplest one consists in keeping the $Q$ clusters defined by the hierarchical tree. A second strategy consists in performing a K-means algorithm with the number of clusters set to $Q$. Another strategy combines the two previous ones. In our study, we used the K-means algorithm under which two conditions must be satisfied: (1) each group contains at least one point, and (2) each point belongs to exactly one group.

To select the variables to incorporate in the MCA/HPC, or equivalently, which variables best describe the fuel poverty situation, thus a "typical profile" a fuel-poor household, we reviewed the literature on fuel-poverty drivers. In Appendix C, we summarise our literature review, based on which we selected the 19 most relevant variables from the "Phébus" dataset to depict fuel poverty. In Table 1, we give these variables that describe both household and dwelling characteristics. To enhance the analysis, we also considered other variables related to the subjective perception of indoor cold, heating restriction behaviour, climate zone and the type of geographic setting.

Table 1 - Variables included in the MCA/HPC (with "Phébus" codes given in parentheses)

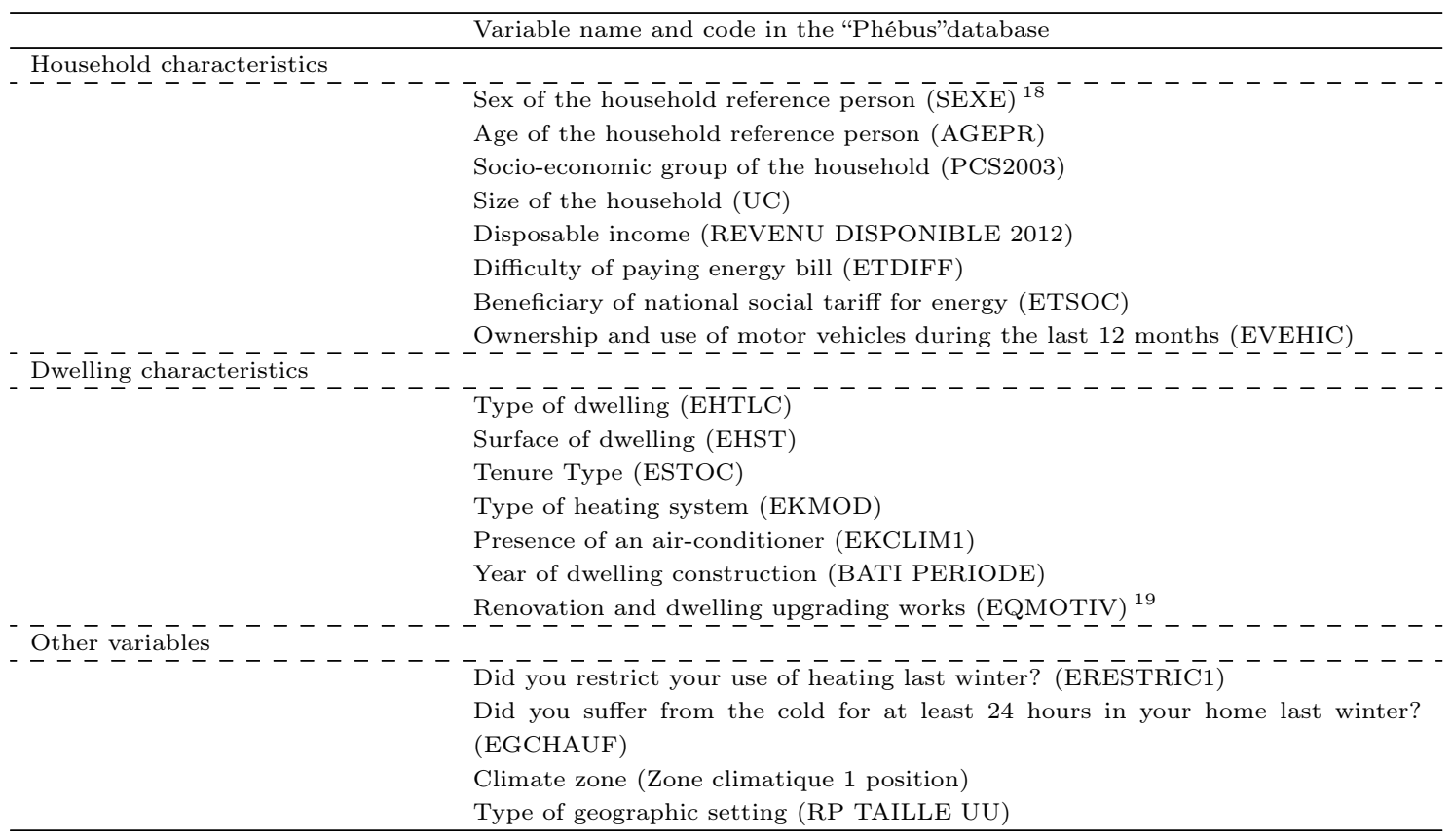

Then, based on the MCA output, we ran an HPC 20 . For each indicator, HPC divides the sample of fuel-poor households into sub-groups, or clusters, having the same characteristics. With this

18. The code name in parentheses associated with each variable in this table refers to the code name of the variable in the "Phébus"database.

19. Depending on data, we consider 2 types of renovation and upgrading works. The first is devoted to decrease energy consumption and to improve heating system quality (EQMOTIV 4 ). The second aims to upgrade dwelling after an energy efficiency diagnostic (EQMOTIV $V_{5}$.

20. To save space and avoid unnecessary detail, we do not give the results of the MCA. We focus on analysing results of the HPC based on which we split the initial set of observed households into several groups having the same profiles. Methodological aspects on how we ran the MCA as well as its results are available upon request. 
detailed description of the fuel-poor by type of indicator, we compared profiles across indicators: which variables best describe the fuel-poor and do their profiles vary across indicators? In other words, do identification processes vary depending on which indicator is used?

Results for the three types of indicator are shown in Figure 2. They show that fuel-poor households are partitioned into four clusters for the $10 \%$ and LIHC $\left(\mathrm{m}^{2}\right)$ indicators and into three clusters for the Thermal Discomfort indicator. Households belonging to the same cluster are homogenous, but differ between clusters. Regardless of the cluster, Table 2 shows that, for each indicator, the ranking of the most represented variables (or associated levels) is different. For example, whereas the first three variables describing the best clusters of the fuel-poor determined using the $10 \%$ indicator are "Beneficiary of the national social tariff for electricity", "Age", "Socio-economic group", for the LIHC $\left(m^{2}\right)$ indicator, they are "Age", "use of communal central heating system ${ }^{21}$ ', and "use of individual central heating system[21. For the Thermal Discomfort indicator, the three most important variables supporting the identification process are "Age", "Type of dwelling", and "Socioeconomic group". Although this indicator shares variables with the $10 \%$ indicator ("Socio-economic group" and "Age") or with the LIHC $\left(m^{2}\right)$ indicator ("Age"), the variable "Type of dwelling" also supports the identification of the fuel-poor according to it.

These preliminary results of the HPC analysis show that although profiles of the fuel-poor are determined according to a set of common variables, or equivalently common characteristics, the importance of each variable in profile identification varies across indicators. This means that the composition of groups depends on which indicator is used. In this context, considering the eight highest ranked variables ${ }^{22}$ Tables 3,4 , and 5 detail the composition of the fuel-poor population for the $10 \%$, LIHC $\left(m^{2}\right)$, and Thermal Discomfort indicators, respectively ${ }^{23}$

\section{Cross-indicator comparison of profiles of the fuel-poor belonging to the most representative clusters}

To interpret our results, we consider, for each indicator, clusters of the fuel-poor with the highest weight, i.e. cluster 2 including $40.38 \%$ of the total fuel-poor population for the $10 \%$ indicator ( $c f$. Table 3), cluster 1 including $31.43 \%$ of the total fuel-poor population for the LIHC $\left(m^{2}\right)$ indicator ( $c f$. Table 4), and cluster 1 including $41.68 \%$ of the total fuel-poor population for the Thermal Discomfort indicator ( $c f$. Table 5). By simultaneously considering the three indicators, we also identified the most represented common variables, namely "Age", "Socio-economic group", "Type of dwelling", "Surface of dwelling", and "Type of heating system". Given these two elements, our results show that the fuel-poor identified using the $10 \%$ and LIHC $\left(\mathrm{m}^{2}\right)$ indicators have similar characteristics with respect to the type and the surface of their dwellings, but different features with respect to their age, socio-economic group and type of heating system. In particular, the two populations of fuel-poor live in large and detached houses, i.e. $>100 \mathrm{~m}^{2}$. Nevertheless, the fuel-poor in cluster 2 using the $10 \%$ indicator are aged from 41 to 60 , are workers and have an independent space heater(s) (or independent heating in each room), whereas those belonging to cluster 1 and determined using the LIHC $\left(\mathrm{m}^{2}\right)$ indicator are elderly, i.e. $>61$ years, belong to a high socio-economic group, i.e. managers or equivalent status, and use an individual central heating systems (boiler or other type of central heating). By extension, when looking at the composition of

21. The original variable was "The type of heating system".

22. In the interest of concision, and because the conclusions are the same, we do not show the results for all 19 variables of the HPC analysis. They are available upon request.

23. To compare profiles across indicators, we shaded the common variables in grey and we indicated the rank of (all) variable(s) or associated levels in parentheses as already presented in Table 2 Some variables have a double ranking. For example, the variable "Type of heating system" from Table 3 is ranked 5 and 6 . This means that the two levels associated with this variable appear as the $5^{\text {th }}$ and $6^{\text {th }}$ most represented levels. They respectively correspond to the "Yes" or "No" answers to the two following questions: "Do you lack a heating system in your dwelling?" and "Do you know what type of heating system do you have in your dwelling?" 

438

24. Because the description of dwelling characteristics of the fuel-poor identified using the $10 \%$ indicator is not available, its is not judicious to compare these profiles with those identified using the LIHC $\left(\mathrm{m}^{2}\right)$ and Thermal Discomfort indicators. The missing information on the dwelling characteristics means that none of the variables are significantly represented in the cluster even if it can be significantly represented inside the total fuel-poor population, i.e. P-value $<2 \%$ (Husson et al., 2016). 
In sum, the HPC made it possible to analyse in detail the characteristics of the fuel-poor 440 population across indicators. It mainly highlighted that the composition of the fuel-poor popu441 lation varies with the indicator. In particular, as presented in Table 2, some variables are more 442 important than others when identifying affected groups, leading to significant profile variability 443 across indicators. Therefore, it is still difficult to identify the fuel-poor population and to depict ${ }_{444}$ a "typical profile". Even if we succeed, this typical profile may exclude a high number of fuel-poor ${ }_{445}$ households, depending on the indicator selected. Some households that are fuel-poor according to 446 one indicator are not necessarily fuel-poor according to another. In this context, our results show 447 that in our sample only 259 households are fuel-poor according the $10 \%$, the LIHC $\left(\mathrm{m}^{2}\right)$, and the ${ }_{448}$ subjective Thermal Discomfort indicators simultaneously, whereas 766 households are fuel-poor 449 according to the $10 \%$ indicator, 592 according to the LIHC $\left(\mathrm{m}^{2}\right)$, and 419 according the Thermal Discomfort indicator.

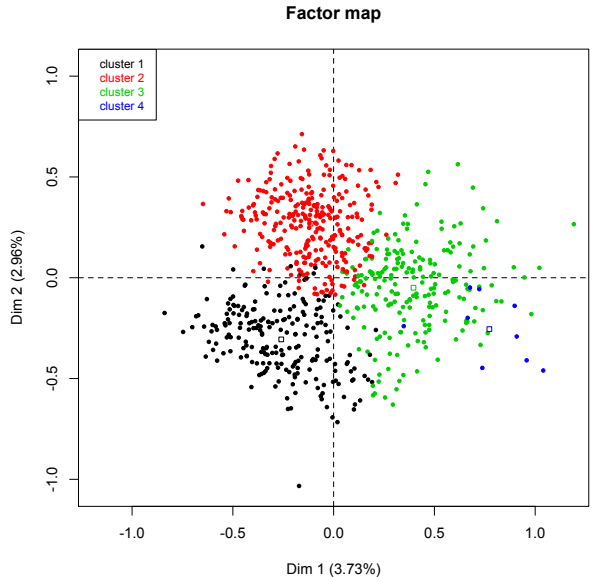

(a)

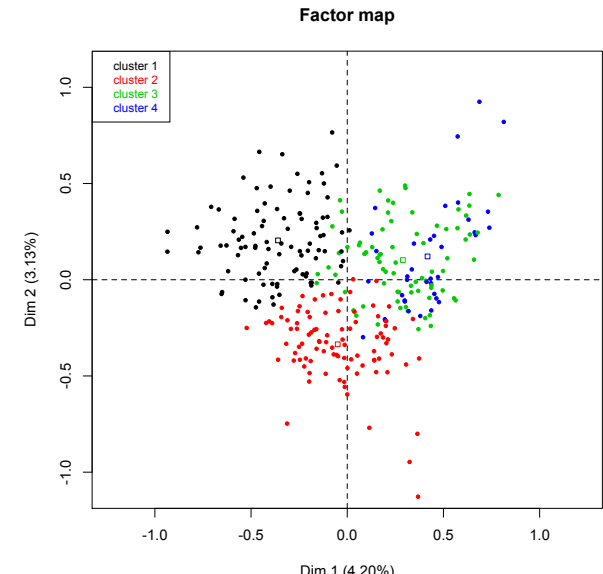

(b)

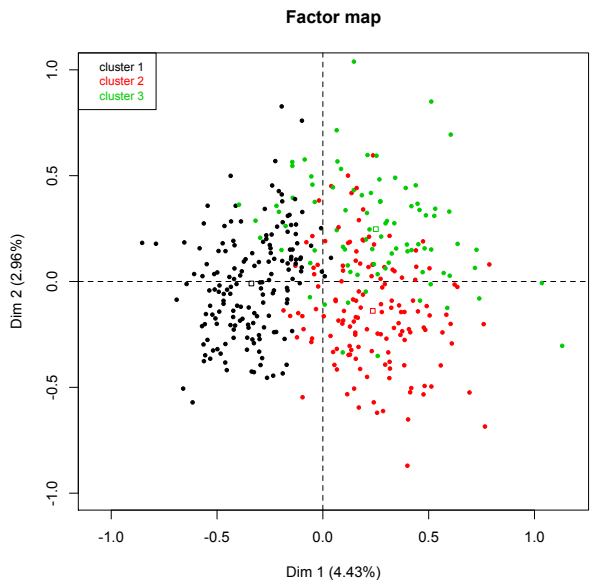

(c)

Figure 2. (a) Clusters according to the $10 \%$ indicator, (b) Clusters according to the LIHC $\left(m^{2}\right)$ indicator, (c) Clusters according to the Thermal Discomfort indicator 
Table 2 - Ranking of the most represented variables within clusters of fuel-poor households (based on a $\chi 2$ test)

\begin{tabular}{|c|c|c|c|}
\hline & \multicolumn{3}{|c|}{ Fuel poverty indicator } \\
\hline \multirow{2}{*}{\multicolumn{4}{|c|}{ 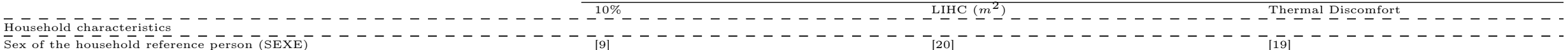 }} \\
\hline & & & \\
\hline $\mathrm{Ag}$ & [2] & [1] & [1] \\
\hline $\begin{array}{l}\text { Socio-economic group of the } \\
\text { Size of the household (UC) }\end{array}$ & [3] & [4] & [3] \\
\hline Disposable income (REVENU DISPONIBLE 2012) & [10] & [13] & [10] \\
\hline Difficult & & & \\
\hline Beneficiary of national social tariff for energy (ETSOC) & $\left.\left.[1]^{25}\right][4] \stackrel{26}{[23]} \stackrel{27}{[12]}\right]^{28},[19]^{29}$ & {$[14][27][23][29][21][26]$} & {$[15][28][21]$} \\
\hline \multicolumn{4}{|c|}{ 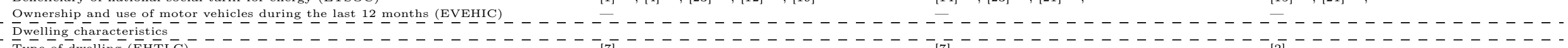 } \\
\hline \multirow{2}{*}{\multicolumn{4}{|c|}{ 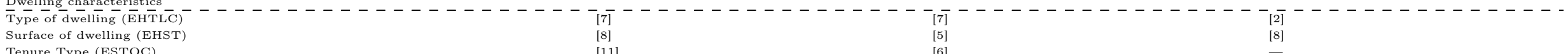 }} \\
\hline & & & \\
\hline $\begin{array}{l}\text { Tenure Type (ESTOC) } \\
\text { Type of heating system (EKMOD) }\end{array}$ & {$[11]$} & 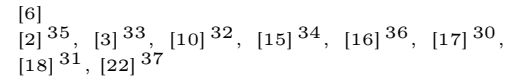 & 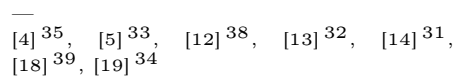 \\
\hline & - & & [22] \\
\hline Year o & [18] & [12] & [7] \\
\hline $\begin{array}{l}\text { and dwelling upgrading works (EQMOTIV) } \\
\text { bles }\end{array}$ & -- & $-\overline{-}----------------$ & $-\overline{-}---------------$ \\
\hline Did & {$[\overline{0}] \overline{-}$} & {$[\overline{11}]$} & \\
\hline & [16] & [9] & \\
\hline & & & [20] \\
\hline Type of geographic setting (RP TAILLE UU) & [14] & [8] & [6] \\
\hline
\end{tabular}


Table 3 - Description of profiles of the most representative fuel-poor households in each cluster according to the $10 \%$ indicator

\begin{tabular}{|c|c|c|c|c|}
\hline \multicolumn{5}{|c|}{ Profile description and weight of the cluster in the total sample } \\
\hline \multirow{2}{*}{\multicolumn{5}{|c|}{ Household characteristics }} \\
\hline & & $\overline{\operatorname{Men}} \overline{(86 . \overline{7} 3 \overline{\%})}---------$ & $\overline{\text { Women }}-\overline{(66.02} \overline{\%})-$ & $\overline{\text { Women }}-\overline{(7 \overline{7}} \overline{7} \overline{7} \overline{\%})^{-------}$ \\
\hline [2] Age of the household reference person (AGEPR) & $\begin{array}{l}{[61-80](63.42 \%)} \\
>80(43.05 \%)\end{array}$ & [41-60] $(80.95 \%)$ & {$[21-40](40.66 \%)$} & {$[21-40](66.67 \%)$} \\
\hline \multirow[t]{2}{*}{ [3] Socio-economic group of the household (PCS2003) } & $\begin{array}{l}\text { Former tradesmen, shopkeepers or } \\
\text { business directors }(21.75 \%)\end{array}$ & Administrative assistants (12.24\%) & $\begin{array}{l}\text { Police officer/Military person- } \\
\text { nel }(19.61 \%)\end{array}$ & Supervisor (44.45\%) \\
\hline & & $\begin{array}{l}\text { Skilled trade worker (trade) } \\
(11.22 \%)\end{array}$ & $\begin{array}{l}\text { Administration and sales pro- } \\
\text { fessionals }(18.66 \%)\end{array}$ & \\
\hline \multirow[t]{2}{*}{ [10] Disposable income (REVENU DISPONIBLE 2012) } & {$[1 \mathrm{e}+04,2 \mathrm{e}+04](52.77 \%)$} & {$[2 \mathrm{e}+04,3 \mathrm{e}+04](42.85 \%)$} & {$[1 \mathrm{e}+04,2 \mathrm{e}+04](44.01 \%)$} & - \\
\hline & {$[1 \mathrm{e}+04,2 \mathrm{e}+04](52.77 \%)$} & {$[3 e+04,4 e+04)(29.25 \%)$} & {$[0,1 \mathrm{e}+04](16.26 \%)$} & - \\
\hline \multirow[t]{2}{*}{ [1][4] Beneficiary of national social tariff for energy (ETSOC) } & Do not qualify $(52.77 \%)$ & Do not know $(99.31 \%)$ & Do not qualify $(81.39 \%)$ & Yes, for electricity $(88.88 \%)$ \\
\hline & \multicolumn{4}{|c|}{ 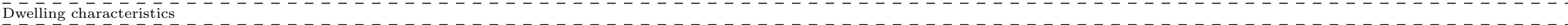 } \\
\hline \multirow{3}{*}{$\begin{array}{l}\text { [7] Type of dwelling (EHTLC) } \\
\text { [8] Surface area of dwelling (EHST) } \\
\text { [5][6] Type of heating system (EKMOD) }\end{array}$} & Detached house $(\overline{9} 0.2 \overline{7} \%)$ & $\begin{array}{l}\text { Detached house }(93.53 \%) \\
{\left[100-150 m^{2}\right](48.29 \%)}\end{array}$ & $\begin{array}{l}\text { Detached house }(37.32 \%) \\
{\left[40-70 m^{2}\right](51.67 \%)}\end{array}$ & - \\
\hline & $\begin{array}{l}\text { Individual central heating } \\
(76.30 \%),\end{array}$ & Indep. space heaters $(46.25 \%)$ & $\begin{array}{l}\text { Individual all-electric heating } \\
(38.27 \%)\end{array}$ & - \\
\hline & Indep. space heaters $(49.07 \%)$ & & Indep. space heaters $(21.05 \%)$ & - \\
\hline
\end{tabular}

Table 4 - Description of profiles of the most representative fuel-poor households according to the LIHC $\left(m^{2}\right)$ indicator

\begin{tabular}{|c|c|c|c|}
\hline \multirow{3}{*}{$\begin{array}{l}\text { Household characteristics } \\
\text { [1] Age of the household reference person }(\overline{A G E P R})\end{array}$} & \multicolumn{2}{|c|}{ Profile description and weight of the cluster in the total sample } & \multirow{3}{*}{ 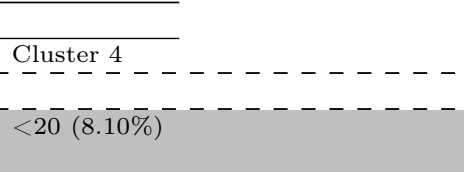 } \\
\hline & Cluster 1 _ $-\ldots$ Cluster 2 & Cluster 3 & \\
\hline & 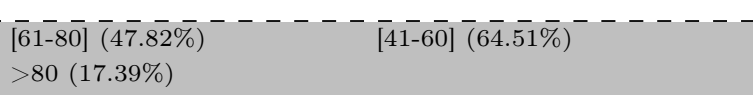 & {$[2 \overline{1}-\overline{4} 0](\overline{4} 8 . \overline{0} 5 \%)$} & \\
\hline \multirow[t]{2}{*}{ [4] Socio-economic group of the household (PCS2003) } & Shop assistants (17.20\%) & $\begin{array}{l}\text { Police officer/Military personnel } \\
(32.46 \%)\end{array}$ & Shop assistants $(24.32 \%)$ \\
\hline & Skilled trade workers $(15.05 \%)$ & $\begin{array}{l}\text { Administrative and sales profession- } \\
\text { als }(16.88 \%)\end{array}$ & $\begin{array}{l}\text { Public sector assistant or worker } \\
(13.51 \%)\end{array}$ \\
\hline $\begin{array}{l}\text { Dwelling characteristics } \\
\overline{[7]}-\overline{T y p e} \text { of } \overline{\text { dwelling }} \overline{(\mathrm{EHTLC})}-\end{array}$ & $\overline{\text { Detached house }} \overline{(91.1 \overline{9} \%)}-$ & Apartment $\overline{(55 . \overline{8} 4 \overline{\%})}-$ & Apartment $(\overline{9} 4 . \overline{99 \%})$ \\
\hline [5] Surface of the dwelling (EHST) & {$\left[100-150 \mathrm{~m}^{2}\right](35.86 \%)$} & $\begin{array}{l}\text { Detached house }(41.55 \%) \\
{\left[40-70 m^{2}\right](41.55 \%)}\end{array}$ & {$\left[1-40 m^{2}\right](51.35 \%)$} \\
\hline
\end{tabular}


Table 4 - Continued

\begin{tabular}{|c|c|c|c|c|}
\hline & \multicolumn{4}{|l|}{$>150 m^{2}(9.78 \%)$} \\
\hline [6] Tenure type (ESTOC) & Homeowners $(75.86 \%)$ & Homeowners $(51.12 \%)$ & Tenants $(62.35 \%)$ & Tenants $(82.35 \%)$ \\
\hline$[2][3][10]$ Type of heating system (EKMOD) & $\begin{array}{l}>150 m^{2}(9.78 \%) \\
\text { Individual }(98.27 \%)\end{array}$ & $\begin{array}{l}\text { Individual central heating }(91.02 \%) \\
\text { Indep. heaters }(24.73 \%)\end{array}$ & $\begin{array}{l}\text { Individual electric heating }(60.13 \%) \\
\text { Indep. heaters }(24.27 \%) \\
\text { Individual central heating }(31.77 \%)\end{array}$ & Communal central heating $(49.64 \%)$ \\
\hline 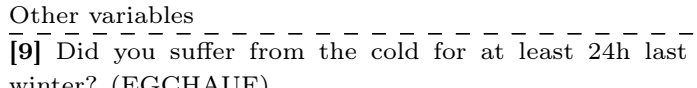 & $\left.\bar{N}_{0}-\overline{94} . \overline{56} \overline{\%}\right)---$ & 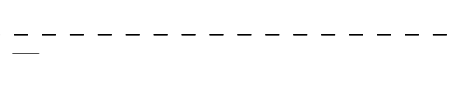 & $\overline{\text { Yes }} \overline{(58 . \overline{4} 4 \overline{\%})}---------$ & 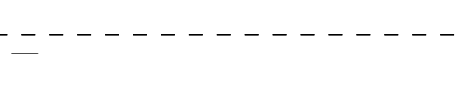 \\
\hline [8] Type of geographical setting (RP TAILLE UU) & $\begin{array}{l}{[200000,1999999](9.89 \%)} \\
\text { Paris }(1.71 \%)\end{array}$ & Rural (18.27\%) & [200000,1999999] $(30.47 \%)$ & Paris $(49.53 \%)$ \\
\hline Weight of the cluster in the sample & $31.43 \%$ & $30.76 \%$ & $25.41 \%$ & $12.40 \%$ \\
\hline
\end{tabular}

Table 5 - Description of profiles of the most representative fuel-poor households in each cluster according to the Thermal Discomfort indicator

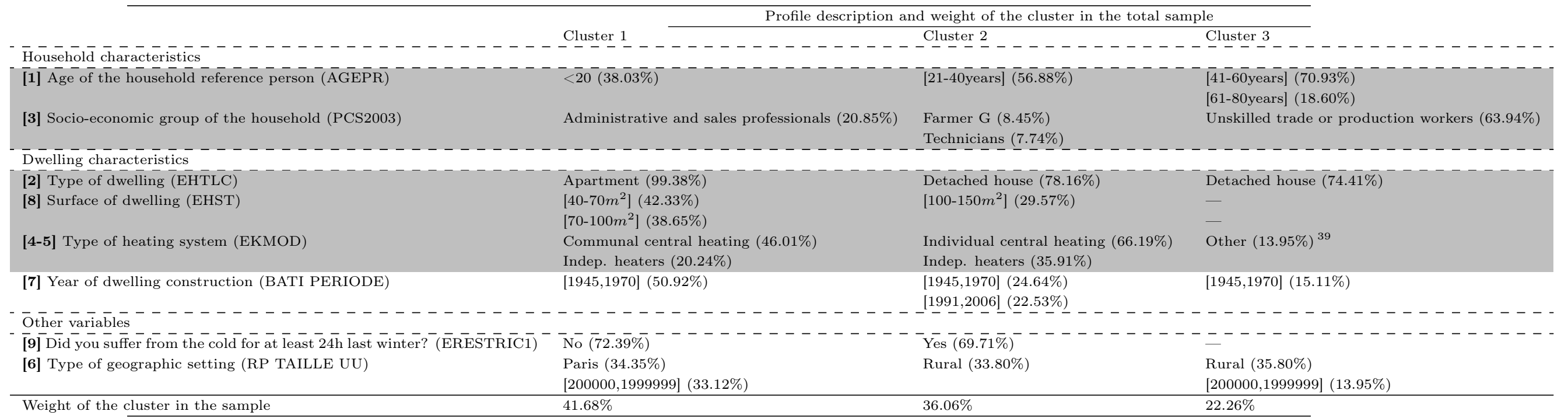

39. This means that households belonging to this cluster use a heating system other than individual central heating (with a boiler or other system), communal central heating (boiler), district heating, individual (built-in) electric heating, mixed (communal and individual), or independent heating equipment. 


\subsection{Intra-indicator analysis: how profiles of fuel-poor households vary depending on the construction of the indicator}

In most cases, fuel poverty has been studied through the narrow use of expenditure-based indicators which are - by construction - based on the definition of exogenous thresholds that lack any theoretical or empirical foundations. In this section, we extend the inter-indicator analysis conducted in previous section by analysing the drawbacks of relying on such exogenous thresholds, particularly in terms of profile variation.

As in section 3.1. we use a data set extracted from the "Phébus" database 2013. To conduct our analysis, we propose a sensitivity analyses based on a logit specification written as follows:

$$
\operatorname{Prob}\left(\mathrm{EP}=1 \mid X_{i}\right)=\alpha+\sum_{i=1}^{13} X_{i}
$$

where $X_{i}$ represents the $i^{\text {th }}$ variable included in the model ( $c f$. Table6). We include both household and dwelling characteristics to better discern differences in fuel-poor profiles. Using other combinations of variables and other models has no impact on our conclusions: in particular, the fuel-poor profiles are highly sensitive to the thresholds chosen. Therefore, slight changes in the threshold change the composition of the population identified as fuel-poor, thus, the target population.

Table 6 - Description of variables included in the logit model

\begin{tabular}{ll}
\hline Variable & Description \\
\hline Isolated women & $=1$ if the person is a woman and single, 0 otherwise \\
Isolated elderly people & $=1$ if the person is older than 59 years and single, 0 otherwise \\
Rural community & $=1$ if the town population has less than 2000 inhabitants, 0 otherwise \\
Thermal discomfort & $=1$ if the person answered yes to "Egchauff' variable, 0 otherwise \\
Limited vehicle use & $=1$ if the person encountered financial difficulties with respect to vehicle use \\
Energy consumption & $=$ quantitative variable taken from Energy Performance Certificate $\left(\mathrm{kWh} / \mathrm{m}^{2}\right)$ \\
Post-1970 building & $=1$ if dwelling was built after 1970,0 otherwise \\
Tenure type & $=1$ if the person is tenant, 0 if owner \\
Energy mix gas vs electricity & $=1$ for gas as heating energy, 0 otherwise \\
Energy mix oil vs electricity & $=1$ for oil as heating energy, 0 otherwise \\
Energy mix other vs electricity & $=1$ for other energy as heating energy (except electricity), 0 otherwise \\
Household size & $=$ size of household $(\mathrm{cu})$ \\
Dwelling size & $=$ size of dwelling $\left(\mathrm{m}^{2}\right)$ \\
\hline
\end{tabular}

a. "Egchauff" variable denotes whether the person answered yes to the question "Did you suffer from the cold last winter?"

We note that the choice of the specification, i.e. logit, probit, complementary log-log, etc., does not matter here because we did not aim to identify the best econometric model to determine fuel-poor households. Instead, we focused on showing the impact of threshold variation on the identification of the fuel-poor population. In other words, we sought to show how some ranges of indicator thresholds lead to identifying some households as fuel-poor and other ranges clearly exclude them.

We consider two threshold-based expenditure indicators, namely the $10 \%$ and the LIHC $\left(m^{2}\right)$. For the $10 \%$ indicator, we modified the original exogenous threshold of $10 \%$ from $0 \%$ to $16 \%$ and examine how it changes the number of households considered as fuel-poor and their characteristics. We used the same methodology with the LIHC $\left(\mathrm{m}^{2}\right)$ indicator. We modify the standard threshold of the median of fuel expenditures, i.e. fuel expenditures per $m^{2}>\mathrm{X}$ times national median expenditures per $m^{2}$, to a value ranging from 0.3 to 1.8. Since the LIHC $\left(m^{2}\right)$ depends on a second threshold ( $c f$. section 2), i.e. equivalised net income $<\mathrm{X}$ times equivalised median net income, we also examined the impact of modifying the two thresholds simultaneously ${ }^{41}$. To save space and

40. This range of values ensures that a sufficient number of observations are available for the estimation of the model, i.e. minimum of 50 observations for $y=1$ and $y=0$.

41. To check the quality of our results, we generated various indices of good discrimination of the model, i.e. AUC 
and Brier criteria.

42. Figures associated with the $10 \%$ indicator are available upon request. We do not report them to save space. The instability of profiles find for LIHC $\left(\mathrm{m}^{2}\right)$ was also observed for the $10 \%$ indicator.

43. The value 0 is not included in the confidence intervals.

44. The P-value associated with the probability of the null assumption is that the coefficient of the variable is not significantly different from zero. 
be included. It is obtained with stepwise selection based on our initial specification (equation 4). This optimal dimension changed greatly when we modified the threshold cut-off ( $c f$. Figure $3(\mathrm{~d})$ ).

For the LIHC $\left(\mathrm{m}^{2}\right)$ indicator, changing the threshold from 0.4 to 1.2 times the median equivalised net income, results in shows (at least) two important changes in the dimension of the model (Figure 3(d) . The first change is identified at a cut-off of 0.42 times the median income. Then, from a cut-off of 0.42 to 0.66 times the median income, we observe a transitional change where variables describing a fuel-poor person are subject to substantial modifications. Finally, in the last stage, the fuel-poor profiles become stable and can be described with eight main variables, i.e. "Rural community", "Limited vehicle use", "Energy Consumption", "Tenant", "Type of heating system", "Household size", "Dwelling size". Unfortunately, the conventional threshold of 0.6 times the median income is in the middle of one of these cut-offs. An alternative conventional way to display the same conclusion is to report the results in terms of econometric output as shown in Table 7 For illustration, we estimate these changes for the income threshold modification of LIHC $\left(m^{2}\right)$. Although some characteristics remain identically targeted regardless of the threshold chosen (like "Tenants" or "Type of heating system"), other characteristics greatly depend on the choice of threshold. If 0.7 times the median income had been chosen instead of the 0.6 times the median income to determine the fuel-poor population, then "Isolated elderly" people and "Rural communities" would be more likely to be targeted.

To display the same result in more concrete terms, we ran the same sensitivity analysis on the threshold applied for the French Energy Voucher. This Voucher corresponds to a new public policy that was launched in France in January 2018 as a measure to fight fuel poverty 45 The Energy Voucher is attributed to the poorest $15 \%$ of households, i.e. less than $€ 7700 / c u$ per year to help them to pay their energy bill. The determination of this particular group of the population is based on income level and on the size of the household $(c u) 45$. Results of the sensitivity analysis show that this threshold targets primarily tenants, rural communities, large households, and small pre-1970 dwellings ( $c f$. Table 8). However, when modifying this threshold by taking a larger part of poor households, for example $30 \%$, leads other sub-groups of the population, such as isolated elderly people, and other types of dwelling, such as dwellings using other heating systems than electric heating systems. This supports, once again, that the target population depends on the construction of indicators, in particular, on their threshold levels.

From a more general point of view, this sensitivity analysis modifying the threshold based on which an Energy Voucher is attributed in France raises the issue of the reliability and relevance of a public policy threshold to target fuel-poor households based on income 46 . Fuel poverty is often associated with income poverty due to the fact that the latter is usually used to capture the monetary aspect of fuel poverty. However, although low incomes can drive fuel poverty, fuel poverty also has other determinants such as energy-inefficient buildings and appliances (Boardman, 2012). In addition, from a purely quantitative point of view, even if there is a relationship between fuel poverty and income poverty, this relationship is not always symmetrical and/or significant. Therefore, as described by Palmer et al. (2008), most fuel-poor households are income-poor but most income-poor households are not fuel-poor 47 . Other scholars argue that fuel and income poverty should be considered as independent phenomena ${ }^{48}$. Therefore, even before analysing how chang-

45. https://www.ecologique-solidaire.gouv.fr/sites/default/files/Rapport $\% 20$ evaluation $\% 20$ cheque $\%$ 20energie.pdf

46. We are grateful to the anonymous reviewer who suggested developing this point.

47. This statement was empirically validated in a study in Spain, showing that only $28.5 \%$ of income-poor are affected by fuel poverty while $79.6 \%$ of the fuel-poor are income-poor (Phimister et al. 2015).

48. According to Phimister et al. (2015) and Ürge Vorsatz and Tirado Herrero (2012), there are two reasons for considering fuel and income poverty separately. First, an event can impact one type of poverty without modifying the other. Second, the consequences of fuel poverty are different from those of income poverty in terms of morbidity 
562 ing the Energy Voucher threshold affects the profile of French fuel-poor households, targeting the 563 fuel-poor based on income appears to be unwise because it can affect the composition of groups, 564 thus, their profiles. 


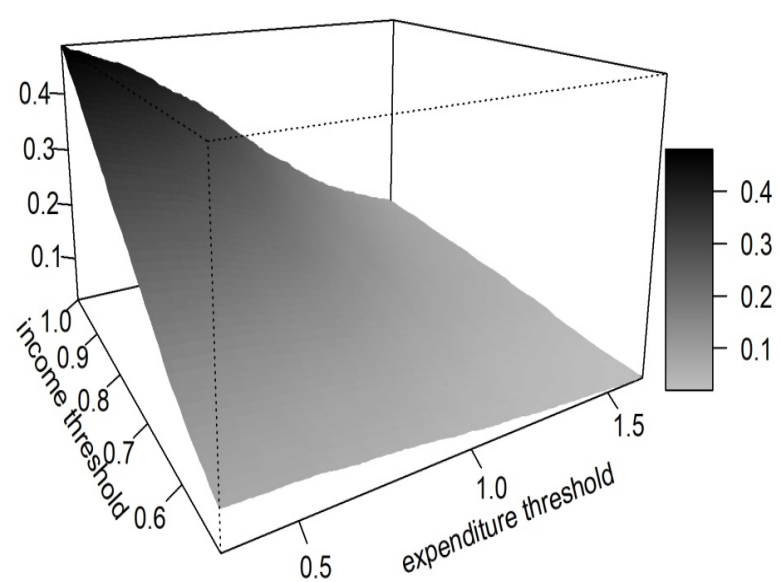

(a)

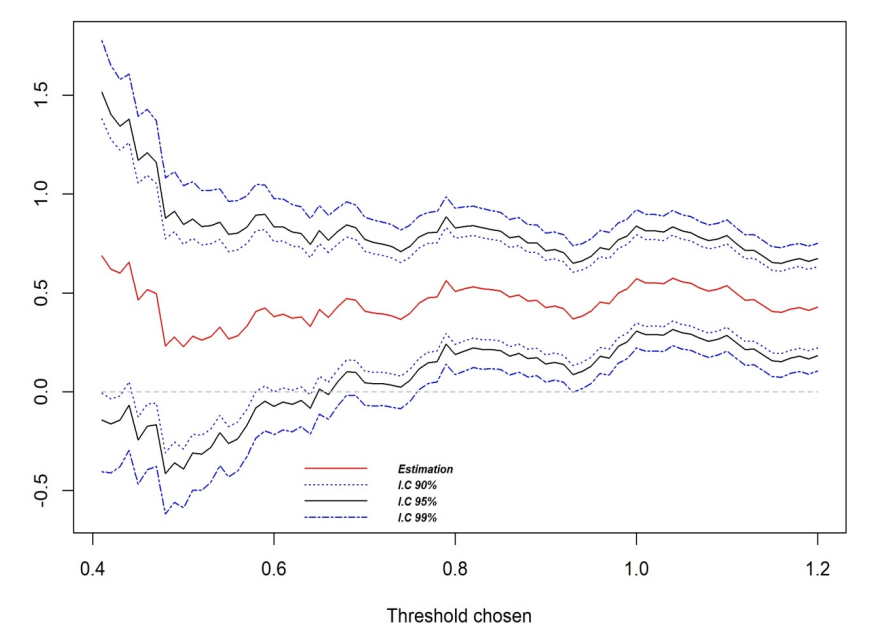

(b)

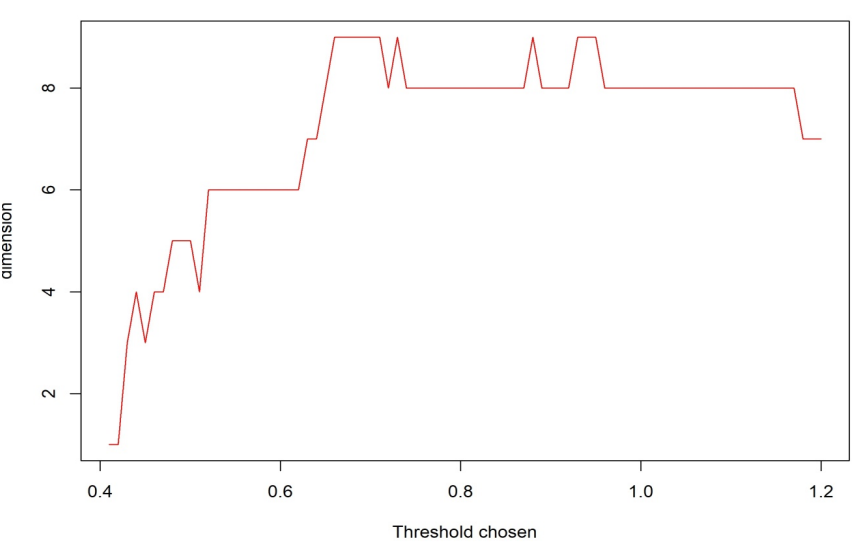

(d)

Figure 3. (a) Variation in the number of fuel-poor households (share of population) as a function of the indicator threshold values for the LIHC indicator, (b) Estimation and confidence intervals for the variable "Sex" according to different threshold levels of the LIHC indicator (variation of only one threshold, i.e. equivalised income $<\mathrm{X}$ times national median income, (c) Statistical significance of the variable "Rural community" in the model according to different values of the two thresholds of the LIHC $\left(\mathrm{m}^{2}\right)$ indicator (flat areas under 0.05 denote statistical significance for this variable whereas peaks indicate level of non-significance), (d) Optimal dimension of the model according to different threshold levels of the LIHC ( $m^{2}$ ) indicator (variation of only one threshold, i.e. equivalised income $<\mathrm{X}$ times $\times$ national median income) 
Table 7 - Sensitivity analysis (1): variation of fuel-poor profiles according to changes in the LIHC $\left(m^{2}\right)$ income threshold

\begin{tabular}{|c|c|c|c|c|c|}
\hline \multirow[t]{2}{*}{$\operatorname{LIHC}\left(m^{2}\right)$} & \multicolumn{5}{|c|}{ Income Threshold } \\
\hline & $0.4 x$ Median & $0.6 \times$ Median & $0.7 x$ Median & $0.8 \mathrm{xMedian}$ & 1xMedian \\
\hline Intercept & $\begin{array}{l}-5.2929 \\
(1.0864) * * * a\end{array}$ & $\begin{array}{l}-3.8671 \\
(0.5441) * * *\end{array}$ & $\begin{array}{l}-3.1977 \\
(0.4428) * * *\end{array}$ & $\begin{array}{l}-2.7761 \\
(0.3943) * * *\end{array}$ & $\begin{array}{l}-2.1294 \\
(0.3325)^{* * *}\end{array}$ \\
\hline Isolated women & $\begin{array}{l}-0.3340 \\
(0.8122)\end{array}$ & $\begin{array}{l}-0.0974 \\
(0.4186)\end{array}$ & $\begin{array}{l}0.0618 \\
(0.3118)\end{array}$ & $\begin{array}{l}0.1746 \\
(0.2750)\end{array}$ & $\begin{array}{l}0.1551 \\
(0.2353)\end{array}$ \\
\hline Rural community & $\begin{array}{l}0.3545 \\
(0.4676)\end{array}$ & $\begin{array}{l}0.3800 \\
(0.2316)\end{array}$ & $\begin{array}{l}0.4079 \\
(0.1849)^{* *}\end{array}$ & $\begin{array}{l}0.5081 \\
(0.1633) * * *\end{array}$ & $\begin{array}{l}0.5718 \\
(0.1356)^{* * *}\end{array}$ \\
\hline Thermal discomfort & $\begin{array}{l}-0.2895 \\
(0.5448)\end{array}$ & $\begin{array}{l}0.2545 \\
(0.2403)\end{array}$ & $\begin{array}{l}0.3542 \\
(0.1979) *\end{array}$ & $\begin{array}{l}0.3102 \\
(0.1811)\end{array}$ & $\begin{array}{l}0.3151 \\
(0.1621)^{*} *\end{array}$ \\
\hline Energy consumption (EPC) & $\begin{array}{l}-0.0002 \\
(0.0014)\end{array}$ & $\begin{array}{l}0.0012 \\
(0.0006)^{* *}\end{array}$ & $\begin{array}{l}0.0014 \\
(0.0005)^{* * *}\end{array}$ & $\begin{array}{l}0.0014 \\
(0.0004)^{* * *}\end{array}$ & $\begin{array}{l}0.0013 \\
(0.0004)^{* * *}\end{array}$ \\
\hline Post-1970 building & $\begin{array}{l}-0.2726 \\
(0.4036)\end{array}$ & $\begin{array}{l}-0.1729 \\
(0.1962)\end{array}$ & $\begin{array}{l}-0.2980 \\
(0.1576) *\end{array}$ & $\begin{array}{l}-0.1562 \\
(0.1385)\end{array}$ & $\begin{array}{l}-0.1059 \\
(0.1165)\end{array}$ \\
\hline Tenure Type & $\begin{array}{l}0.8650 \\
(0.4439) *\end{array}$ & $\begin{array}{l}0.6821 \\
(0.2150) * * *\end{array}$ & $\begin{array}{l}0.7220 \\
(0.1762)^{* * *}\end{array}$ & $\begin{array}{l}0.6784 \\
(0.1576)^{* * *}\end{array}$ & $\begin{array}{l}0.5387 \\
(0.1393)^{* * *}\end{array}$ \\
\hline Energy mix gas $v s$ electricity & $\begin{array}{l}0.5368 \\
(0.4618)\end{array}$ & $\begin{array}{l}0.9115 \\
(0.2376)^{* * *}\end{array}$ & $\begin{array}{l}0.9247 \\
(0.1941)^{* * *}\end{array}$ & $\begin{array}{l}1.1057 \\
(0.1692)^{* * *}\end{array}$ & $\begin{array}{l}0.8835 \\
(0.1397)^{* * *}\end{array}$ \\
\hline Dwelling size & $\begin{array}{l}-0.0009 \\
(0.0049)\end{array}$ & $\begin{array}{l}-0.0175 \\
(0.0036)^{* * *}\end{array}$ & $\begin{array}{l}-0.0172 \\
(0.0028)^{* * *}\end{array}$ & $\begin{array}{l}-0.0182 \\
(0.0025)^{* * * *}\end{array}$ & $\begin{array}{l}-0.0178 \\
(0.0020)^{* * *}\end{array}$ \\
\hline Observations & 2076 & 2076 & 2076 & 2076 & 2076 \\
\hline Brier & 0.013 & 0.056 & 0.085 & 0.109 & 0.155 \\
\hline AUC & 0.717 & 0.797 & 0.792 & 0.781 & 0.768 \\
\hline
\end{tabular}

a. ${ }^{* * *}$ significant at $\mathrm{P}<1 \%, * * 5 \%$ or * $10 \%$. 
Table 8 - Sensitivity analysis (2): probability of qualifying for the French Energy Voucher programme according to the equivalised income threshold

\begin{tabular}{|c|c|c|c|c|c|c|c|}
\hline \multirow[b]{2}{*}{$\begin{array}{l}\text { Threshold (share of the poorest } \\
\text { population) }\end{array}$} & \multicolumn{7}{|c|}{ Income $/ \mathrm{cu}$} \\
\hline & 0.05 & 0.1 & 0.15 & 0.2 & 0.25 & 0.3 & 0.35 \\
\hline Intercept & $\begin{array}{l}-4.8188 \\
(0.6904) * * * a\end{array}$ & $\begin{array}{l}-4.1180 \\
(0.4975) * * *\end{array}$ & $\begin{array}{l}-3.2365 \\
(0.4075)^{* * *}\end{array}$ & $\begin{array}{l}-2.7629 \\
(0.3638)^{* * *}\end{array}$ & $\begin{array}{l}-2.5610 \\
(0.3351)^{* * *}\end{array}$ & $\begin{array}{l}-2.1868 \\
(0.3198)^{* * *}\end{array}$ & $\begin{array}{l}-1.9679 \\
(0.3060)^{* * *}\end{array}$ \\
\hline Isolated women & $\begin{array}{l}0.6569 \\
(0.5494)\end{array}$ & $\begin{array}{l}0.2255 \\
(0.3847)\end{array}$ & $\begin{array}{l}0.5208 \\
(0.3018) *\end{array}$ & $\begin{array}{l}0.4229 \\
(0.2631)\end{array}$ & $\begin{array}{l}0.3917 \\
(0.2418)\end{array}$ & $\begin{array}{l}0.4380 \\
(0.2270)^{*}\end{array}$ & $\begin{array}{l}0.3621 \\
(0.2181)^{*}\end{array}$ \\
\hline Isolated elderly people & $\begin{array}{l}0.4495 \\
(0.5699)\end{array}$ & $\begin{array}{l}0.6777 \\
(0.3812)^{*}\end{array}$ & $\begin{array}{l}0.2152 \\
(0.3133)\end{array}$ & $\begin{array}{l}0.5199 \\
(0.2665)^{*}\end{array}$ & $\begin{array}{l}0.4728 \\
(0.2441)^{*}\end{array}$ & $\begin{array}{l}0.5294 \\
(0.2288)^{* *}\end{array}$ & $\begin{array}{l}0.6304 \\
(0.2187)^{* * *}\end{array}$ \\
\hline Rural community & $\begin{array}{l}0.4597 \\
(0.2991)\end{array}$ & $\begin{array}{l}0.5656 \\
(0.2071)^{* * *}\end{array}$ & $\begin{array}{l}0.4251 \\
(0.1701)^{* *}\end{array}$ & $\begin{array}{l}0.4704 \\
(0.1509)^{* * *}\end{array}$ & $\begin{array}{l}0.4541 \\
(0.1384)^{* * *}\end{array}$ & $\begin{array}{l}0.5614 \\
(0.1309)^{* * *}\end{array}$ & $\begin{array}{l}0.4441 \\
(0.1250)^{* * *}\end{array}$ \\
\hline Thermal discomfort & $\begin{array}{l}0.2401 \\
(0.3164)\end{array}$ & $\begin{array}{l}0.2225 \\
(0.2257)\end{array}$ & $\begin{array}{l}0.2291 \\
(0.1885)\end{array}$ & $\begin{array}{l}0.4337 \\
(0.1689)^{* *}\end{array}$ & $\begin{array}{l}0.2505 \\
(0.1625)\end{array}$ & $\begin{array}{l}0.2994 \\
(0.1584)^{*}\end{array}$ & $\begin{array}{l}0.2134(0.1568) \\
(0.1568)\end{array}$ \\
\hline Limited vehicle use & $\begin{array}{l}0.7910 \\
(0.2835)^{* * *}\end{array}$ & $\begin{array}{l}0.8797 \\
(0.2012)^{* * *}\end{array}$ & $\begin{array}{l}1.0467 \\
(0.1683)^{* * *}\end{array}$ & $\begin{array}{l}0.8606 \\
(0.1585)^{* * *}\end{array}$ & $\begin{array}{l}0.7780 \\
(0.1533)^{* * *}\end{array}$ & $\begin{array}{l}0.9578 \\
(0.1511)^{* * *}\end{array}$ & $\begin{array}{l}1.0814 \\
(0.1523) * * *\end{array}$ \\
\hline Energy consumption & $\begin{array}{l}-0.0001 \\
(0.0009)\end{array}$ & $\begin{array}{l}0.0008 \\
(0.0006)\end{array}$ & $\begin{array}{l}0.0005 \\
(0.0005)\end{array}$ & $\begin{array}{l}0.0001 \\
(0.0004)\end{array}$ & $\begin{array}{l}0.0005 \\
(0.0004)\end{array}$ & $\begin{array}{l}0.0004 \\
(0.0004)\end{array}$ & $\begin{array}{l}0.0005 \\
(0.0004)\end{array}$ \\
\hline Post-1970 building & $\begin{array}{l}-0.4323 \\
(0.2556)^{*}\end{array}$ & $\begin{array}{l}-0.2044 \\
(0.1803)\end{array}$ & $\begin{array}{l}-0.4190 \\
(0.1464)^{* * *}\end{array}$ & $\begin{array}{l}-0.3648 \\
(0.1298)^{* * *}\end{array}$ & $\begin{array}{l}-0.3118 \\
(0.1191)^{* * *}\end{array}$ & $\begin{array}{l}-0.2196 \\
(0.1132)^{*}\end{array}$ & $\begin{array}{l}-0.2260 \\
(0.1083)^{* *}\end{array}$ \\
\hline Tenure Type & $\begin{array}{l}0.5540 \\
(0.2854)^{*}\end{array}$ & $\begin{array}{l}0.7137 \\
(0.1992) * * *\end{array}$ & $\begin{array}{l}0.7580 \\
(0.1648)^{* * *}\end{array}$ & $\begin{array}{l}0.8283 \\
(0.1484)^{* * *}\end{array}$ & $\begin{array}{l}0.9646 \\
(0.1386) * * *\end{array}$ & $\begin{array}{l}0.9693 \\
(0.1348)^{* * *}\end{array}$ & $\begin{array}{l}0.9892 \\
(0.1330)^{* * *}\end{array}$ \\
\hline Energy mix gas vs electricity & $\begin{array}{l}0.3175 \\
(0.2841)\end{array}$ & $\begin{array}{l}0.3123 \\
(0.2100)\end{array}$ & $\begin{array}{l}0.2500 \\
(0.1705)\end{array}$ & $\begin{array}{l}0.2936 \\
(0.1511)^{*}\end{array}$ & $\begin{array}{l}0.3265 \\
(0.1385)^{* *}\end{array}$ & $\begin{array}{l}0.3607 \\
(0.1320)^{* * *}\end{array}$ & $\begin{array}{l}0.2527 \\
(0.1258)^{* *}\end{array}$ \\
\hline Energy mix oil $v s$ electricity & $\begin{array}{c}-0.8323 \\
(0.5518)\end{array}$ & $\begin{array}{l}0.1049 \\
(0.2905) \\
\end{array}$ & $\begin{array}{l}0.0621 \\
(0.2348) \\
\end{array}$ & $\begin{array}{l}0.2716 \\
(0.1999)\end{array}$ & $\begin{array}{l}0.2326 \\
(0.1837)\end{array}$ & $\begin{array}{l}0.4014 \\
(0.1707)^{* *}\end{array}$ & $\begin{array}{l}0.3780 \\
(0.1620)^{* *}\end{array}$ \\
\hline Energy mix other $v s$ electricity & $\begin{array}{l}0.1656 \\
(0.5662)\end{array}$ & $\begin{array}{l}0.1494 \\
(0.4173)\end{array}$ & $\begin{array}{l}0.3091 \\
(0.3277)\end{array}$ & $\begin{array}{l}0.2740 \\
(0.3000)\end{array}$ & $\begin{array}{l}0.4479 \\
(0.2716)^{*}\end{array}$ & $\begin{array}{l}0.5176 \\
(0.2608)^{* *}\end{array}$ & $\begin{array}{l}0.4408 \\
(0.2544) *\end{array}$ \\
\hline Household size & $\begin{array}{l}1.1392 \\
(0.2354)^{* * *}\end{array}$ & $\begin{array}{l}1.1606 \\
(0.1778)^{* * *}\end{array}$ & $\begin{array}{l}0.9781 \\
(0.1489)^{* * *}\end{array}$ & $\begin{array}{l}0.9789 \\
(0.1347)^{* * *}\end{array}$ & $\begin{array}{l}0.9040 \\
(0.1253)^{* * *}\end{array}$ & $\begin{array}{l}0.8728 \\
(0.1208)^{* * *}\end{array}$ & $\begin{array}{l}0.8931 \\
(0.1165)^{* * *}\end{array}$ \\
\hline Dwelling size & $\begin{array}{l}-0.0095 \\
(0.0043)^{* *}\end{array}$ & $\begin{array}{l}-0.0138 \\
(0.0032)^{* * *}\end{array}$ & $\begin{array}{l}-0.0107 \\
(0.0024)^{* * *}\end{array}$ & $\begin{array}{l}-0.0111 \\
(0.0021)^{* * *}\end{array}$ & $\begin{array}{l}-0.0099 \\
(0.0018)^{* * *}\end{array}$ & $\begin{array}{l}-0.0113 \\
(0.0018)^{* * *}\end{array}$ & $\begin{array}{l}-0.0106 \\
(0.0016)^{* * *}\end{array}$ \\
\hline Observations & 2076 & 2076 & 2076 & 2076 & 2076 & 2076 & 2076 \\
\hline Brier & 0.032 & 0.065 & 0.099 & 0.126 & 0.150 & 0.167 & 0.182 \\
\hline AUC & 0.735 & 0.757 & 0.748 & 0.740 & 0.732 & 0.740 & 0.737 \\
\hline
\end{tabular}

a. ${ }^{* * *}$ significant at $\mathrm{P}<1 \%, * * \mathrm{P}<5 \%$ or $* \mathrm{P}<10 \%$ 


\section{Discussion and recommendations}

Our results demonstrate how the determination of the fuel-poor population depends on the choice of the fuel poverty indicator and its construction (threshold). Results from different indicators can be different or even conflicting, i.e. a person identified as fuel-poor according to one indicator, may not be according to another. Although this issue has been already raised in the literature, it remains unresolved and even unmeasured in the majority of studies. However, this issue greatly affects the determination of the magnitude of fuel poverty as well as the fuel-poor profiles, and calls into question the effectiveness of identifying fuel-poor households and of policies aiming to fight fuel poverty. The widespread use of indicators with no theoretical foundation paves the way to using a given indicator or threshold to favour a particular fuel-poor profile. Given that we have revealed the empirical importance of the issue, we argue that new methodologies are needed to overcome the limits of conventional indicators, thus to measure fuel poverty in a more effective way. Below, we give some recommendations.

\section{Combining conventional indicators with a sensitivity analysis}

When aiming to determine the fuel-poor population and analyse its profile, several types of conventional indicators can be used. For example, to measure the extent and composition of fuel poverty in France, Legendre and Ricci (2015) use three objective indicators, namely the $10 \%$, the AFCP and the LIHC. They conclude that the share of fuel-poor households and their characteristics differ significantly depending on which indicator they use. More recently, Papada and Kaliampakos (2016) combined the objective 10\% indicator with subjective indicators to mesure fuel poverty in Greece. This combined approach should be generalised. In this context, in France, the French National Observatory of Fuel Poverty suggests using two approaches to measure fuel poverty (ONPE, 2016). The first one is based on the combined use of three objective expenditure indicators, i.e. the $10 \%$, LIHC $(c u)$ and LIHC $\left(m^{2}\right)$ indicators, and the second is based on the subjective Thermal Discomfort indicator.

Although results of several indicators can differ, comparing them helps to analyse in detail the characteristics of fuel-poor households. One way to ensure results of combined conventional indicators is to associate each indicator outcome with a sensitivity analysis. The aim is to highlight how results change depending on the type of indicator or on its construction, i.e. threshold level. This approach leads to a reliable identification process, based on which the necessary policies targeting the elimination of fuel poverty can be implemented (Dubois, 2012).

\section{Alternative use of threshold-based indicators}

Another way to deal with the variation in the profiles of the fuel-poor when using conventional threshold-based indicators is to use them without the thresholds. For instance, the evolution of fuel poverty can be tracked using the median of the fuel-poverty ratio as well as the skewness and kurtosis of its distribution. As shown in Figure 4 a shift in the median value can indicate a worsening situation whereas a shift in the symmetry of the curve can suggest an improvement with less inequality. Conversely, the skewness of the distribution can indicate a worsening situation for the most exposed fuel-poor. Obviously, these indicators do not provide any head counts of the fuel-poor population and cannot quantitatively analyse the spread of the phenomenon. Nevertheless, they give an interesting complementary overview of the temporal dynamics of fuel poverty. 


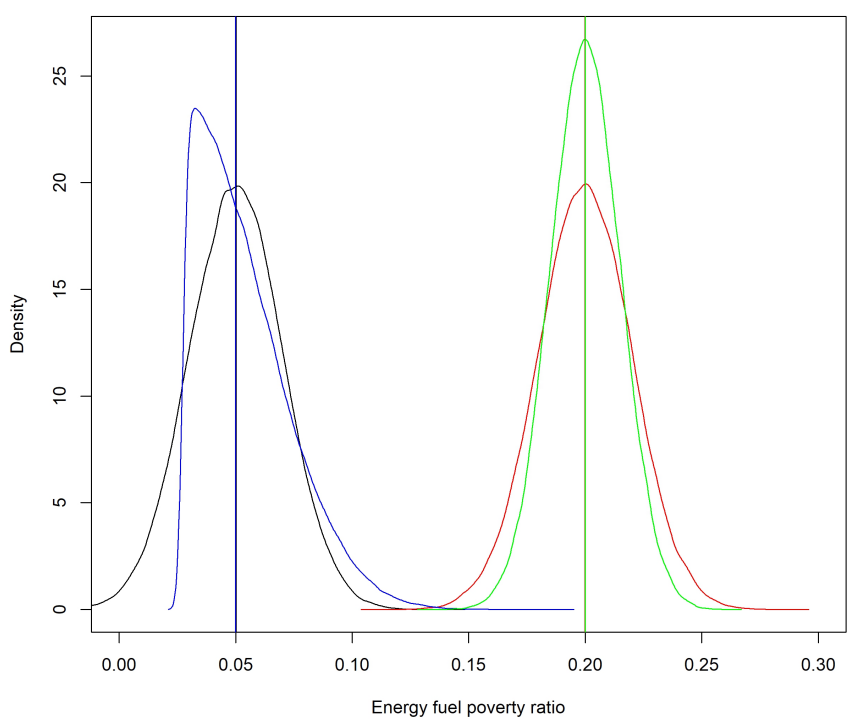

Figure 4. Alternative way of examining expenditure-based indicators: evolution of the distribution of the $10 \%$ indicator Note: An arbitrary threshold is not necessarily required to analyse the dynamics of fuel poverty. Distribution shifts and asymmetry of the fuel-poor population can represent an unbiased exploratory means to consider the issue.

\section{Using new types of indicator}

Given that there is currently no commonly accepted approach to measure fuel poverty, several recent studies have proposed tackling the issue by constructing new types of indicator(s). In this context, in addition to measuring fuel poverty by using the most common subjective indicators, i.e. arrears on utility bills, inability to keep the home adequately warm and the presence of damp walls and leaks, Papada and Kaliampakos (2016) constructed new indicators focusing on health problems caused by poor heating conditions and restriction of other essential needs such as food or clothing (essential for meeting energy needs).

In a more general framework, other studies call for the construction of indicators, so-called composite indices, taking into account the multidimensional nature of fuel poverty. In particular, Okushima (2017) constructed a multidimensional energy poverty index (MEPI) that considers three attributes of fuel poverty, namely energy costs, income and dwelling energy efficiency. Similarly, Charlier and Legendre (2016) built an index that takes into account household heating restrictions in addition to monetary constraints and dwelling energy efficiency.

By extension, some recent studies based on energy deprivation, a concept commonly applied to developing countries, call for the revision the conceptual framework that form the basis for the construction of the conventional indicators of fuel poverty in developed countries. In particular, they advocate the definition and the use of indicators coming from the energy capabilities framework (Sen (1992), Nussbaumer et al. (2003), Nussbaumer et al. (2012)). This framework is based on the argument that the energy demand is not for energy per se, but for the services energy use can provide such as lighting, cooking, heating and cooling. Therefore, Smith and Seward (2009) distinguish between basic and secondary capabilities 49 Day et al. (2016) apply this capabilities approach to argue why energy is used and needed and to propose a innovative multidimensional

49. Basic capabilities are those that can be defined in broad and generic forms and are considered as the most fundamental, for example education, bodily health and social respect. Secondary capabilities are rather seen as component parts of materialising basic capabilities such as having access to information, using machinery and preparing food. 
definition of energy poverty that integrates approaches to energy poverty from global North and South contexts. They argue that the energy capabilities framework idenfities several areas of intervention to address the problem of energy poverty, in particular, the energy poverty in the context of climate change.

\section{Conclusion}

During the last decade, the literature on fuel poverty has gained growing interest. Although it has offered and applied many objective and subjective indicators to measure fuel poverty, it has failed to reach a consensus on the appropriate indicator to use to reliably identify affected households and implement appropriate public policies to help them to overcome the problem. Clearly, there is a trend in the use of indicators, such as for example the increasing use of the $10 \%$ indicator after its official use by the UK government in 2001. Similarly, the LIHC indicator has been well received since its first appearance in Hills (2011, 2012) reports. Nonetheless, several discursive criticisms related to the use of these indicators have been extensively relayed in the past few years. Although many are valid, they clearly lack empirical support.

The aim of this study was to fill this theorectical-emprical gap. In particular, based on a critical review of the literature on fuel poverty indicators, we focused on two issues. First, because fuel poverty indicators have neither real theoretical foundations nor any empirical consensus as to the identification of the fuel-poor, we investigated how the use of one indicator over another can lead to the exclusion of some part of the affected population from being targeted by public policy measures devoted to fighting the problem. Further, in the case of exclusion, we sought to determine which trade-off is at work and how it is applied, i.e. type of indicator and/or its threshold. Second, we examined the associated crucial question of the homogeneity of the profiles of the fuel-poor population and its impact on the implementation, the reliability and the relevance of public policy targeting. To address these issues, we analysed in detail the impact of the choice of indicators on the identification of the fuel-poor population, in particular, on their profile description.

Our results show that the profile of the fuel-poor depends on the indicator selected and on its construction, i.e. threshold level in the case of expenditure indicators. In particular, the interindicator analysis based on an HCA showed that the fuel-poor population determined with a given indicator pools several types of profile and that profile groups can differ across indicators. We then detailed the characteristics of some selected representative fuel-poor households. Similarly, the intra-indicator analysis showed that profiles of the fuel-poor as well as the size of groups, or equivalently, the magnitude of fuel poverty has high elasticity for the level of the threshold. In this context, by focusing on the French Energy Voucher as a policy to fight fuel poverty, we also showed how the targeted fuel-poor population changes when changing the policy threshold currently set in France at the poorest $15 \%$ of households. Based on these results, we highlight the difficulty of identifying and defining a "typical profile" of a fuel-poor household for the implementation of public policies.

We argue that both scholars and policy-makers should be aware of the potential trade-offs involved in the use of a given indicator or a given threshold. Some indicators or thresholds favour some groups of population and exclude others. We recommend employing different strategies to deal with these issues, namely the combined use of conventional indicators associated with a sensitivity analysis, the omission of thresholds from expenditure-based indicators, and the use of new types of indicator based on a more suitable conceptual framework. Obviously, these strategies are not mutually exclusive and can be carried out together.

The difficulty of identifying the fuel-poor population reveals that there are still a lot of things 
68о to learn about fuel poverty. There are in particular three main fields of research to be explored.

${ }_{681}$ First, because fuel poverty is basically a dynamic phenomenon, analysing this question can help

682 understand its duration as a function of the profiles of affected groups. Interestingly, it can also

683 help analyse the effectiveness and enforcement of policies to combat fuel poverty. Second, there is a

${ }_{684}$ need to better understand the drivers of fuel poverty by distinguishing exogenous and endogenous

${ }_{685}$ determinants to identify the most interesting levers that can help overcome the problem. Last,

${ }_{686}$ but not least, studies dealing with the relationship between fuel poverty and other poverty-related

${ }_{687}$ concepts such as monetary poverty, heath, education and social exclusion, should be conducted.

${ }_{688}$ The analysis of interactions between these different issues may reveal causal and cumulative effects

689 necessary to understand and, thus, to eliminate fuel poverty.

\section{Acknowledgments}

691 The authors wish to express their gratitude to the Editorial Board of the FAERE, in particular 692 to the anonymous referee for his/her helpful comments on a preliminary version of this article. They

${ }_{693}$ also thank Soán Lyons and John Curtis from the "Economic and Social Research Institute" (ESRI)

${ }_{694}$ (Dublin) for their detailed and very useful comments and suggestions on a preliminary version of

695 the article. This study was financially supported by the French Energy Council ("Conseil Français

696 de l'Energie" (CFE)).

697 All remaining errors remain with the authors. The usual disclaimer applies. 
${ }_{698}$ A Brief literature review on fuel poverty indicators, their advantages and their drawbacks

Table A.1 - Brief literature review on fuel poverty indicators, their advantages and their drawbacks

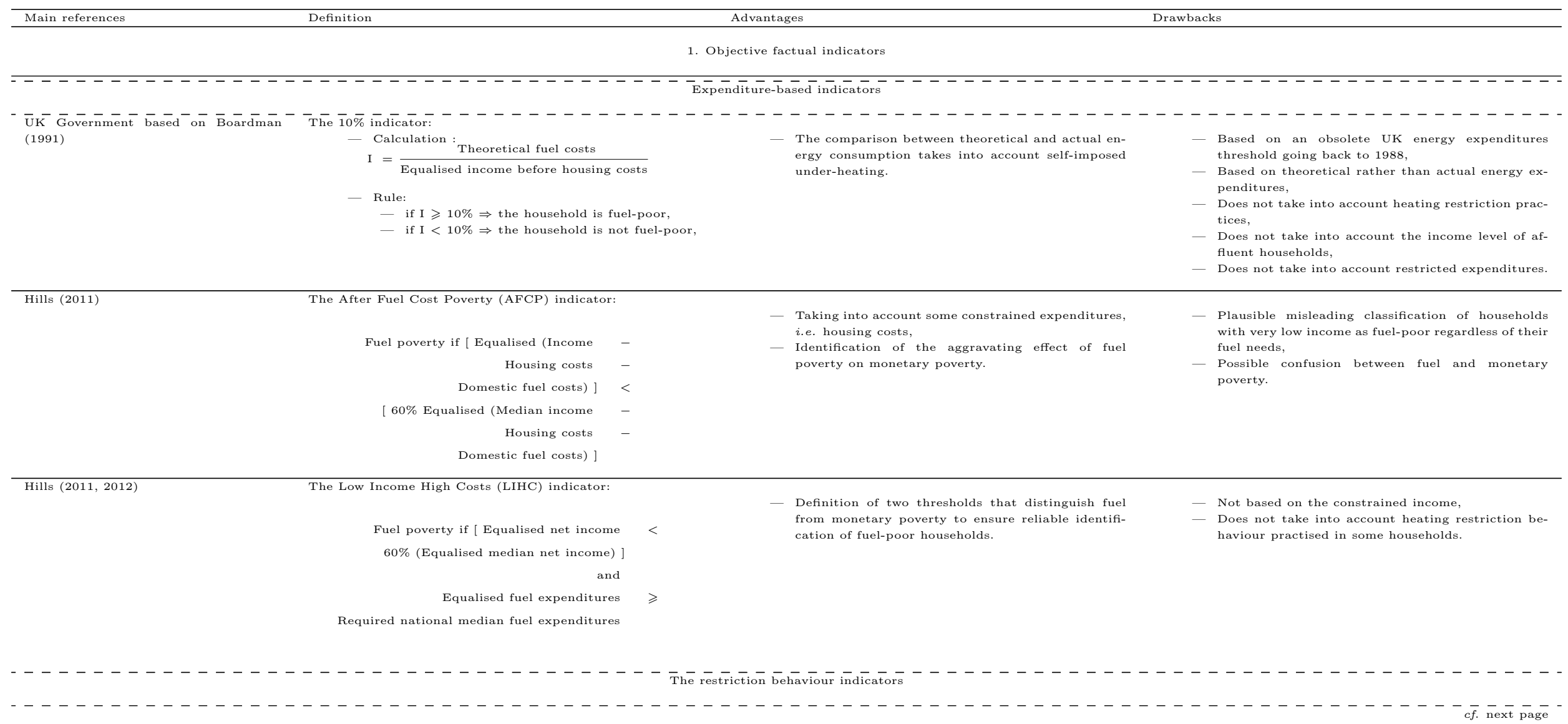


Table A.1 - Continued

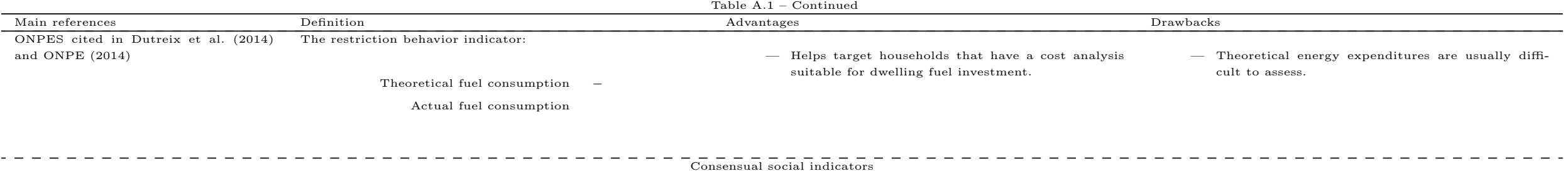

Also cf. summary of Healy and Clinch 2002, and Nussbaumer et al. 2012, presented in the section entitled "Composite indices" in this table)

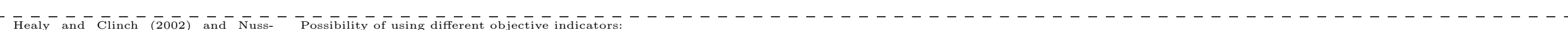

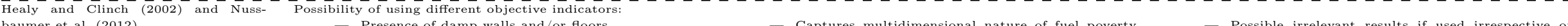

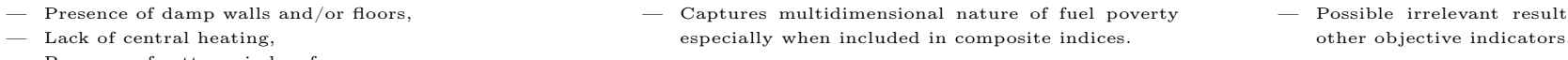

- Presence of rotten window frames,

Access to electricity distribution,

2. Subjective self-reported indicator

\section{Composite indices 50}

Composite weighted index based on the combination of six consensual social indicators whic

Are split into two sub-groups: subjective self-

reported and objective factual indicators

Pertains to household finances (fuel and utility
bills), the state of the building structure (presence

of damp or rot), and the dwelling's heating system.
- Associates objective and subjective criteria,
- Suitable for cross-country comparisons.
Assignments of weights to each indicator incorporated in the composite indice is somewhat arbitrary Results vary

50. References cited in this part of the table present indices that were constructed for developed countries. Therefore, if applied to a developing country, some refinements will be necessary, especially with regard to the definition of the dimensions of poverty. In fact, when considering energy poverty in developing countries, most existing studies focus on the question of energy access, not on thermal comfort as in developed countries. 
Table A.1 - Continued

\begin{tabular}{|c|c|c|c|}
\hline Main references & Definition & Advantages & $\begin{array}{l}\text { Drawbacks } \\
\end{array}$ \\
\hline \begin{tabular}{|l|l|} 
Thomson and Snell 2013) \\
\end{tabular} & $\begin{array}{l}\text { Composite weighted index based on the combination of three } \\
\text { proxy indicators, namely the presence of arrears on utility } \\
\text { bills in last } 12 \text { months, the presence of a leaking roof, damp } \\
\text { walls or rotten windows and the ability to pay to keep the } \\
\text { home adequately warm. }\end{array}$ & - Suitable for cross-country comparisons. & $\begin{array}{l}\text { - Assignments of weights to each proxy indicator is } \\
\text { somewhat arbitrary, } \\
\text { - Results vary depending on the weight assigned to } \\
\text { each indicator. }\end{array}$ \\
\hline Fabbri 2015) & $\begin{array}{l}\text { Composite index, the so-called Building Fuel Poverty Index } \\
\text { (BFP), aims to assess the relationship between building en- } \\
\text { ergy performance, dwelling habits and fuel poverty. }\end{array}$ & $\begin{array}{l}\text { - Focusing on the role of dwelling energy efficiency as } \\
\text { a driver of fuel poverty, } \\
\text { - the index identifies subjects that can afford to pay } \\
\text { for building energy refurbishment. }\end{array}$ & $\begin{array}{l}\text { - Not generally easy to apply in countries other than } \\
\text { Italy. }\end{array}$ \\
\hline \begin{tabular}{|l|l|} 
Okushima & 2017 \\
\end{tabular} & $\begin{array}{l}\text { Composite index, the so-called Multidimensional Energy } \\
\text { Poverty Index (MEPI), which is composed of three attributes } \\
\text { of energy poverty, namely energy costs, income and dwelling } \\
\text { energy efficiency. }\end{array}$ & $\begin{array}{l}\text { - Considers the multidimensional nature of energy } \\
\text { poverty which matches the original concept of en- } \\
\text { ergy poverty by Boardman } 1991] \text {. }\end{array}$ & $\begin{array}{l}\text { - Does not take into account the subjective dimension } \\
\text { of fuel poverty. }\end{array}$ \\
\hline
\end{tabular}




\section{B Details on the computation of fuel poverty rates}

We start by giving below the list of variables (with their acronyms) that we extract from "Phébus" database to calculate fuel poverty rates. Then we explain how we calculate fuel poverty rates according to the $10 \%$, LIHC, and the Thermal Discomfort indicators.

- Variables used to calculate fuel costs:

— "MONTANT ELEC 2012": annual amount of electricity

— "MONTANT GAZ 2012": annual amount of gas expenditures

— "MONTANT FIOUL 2012": annual amount of heating oil expenditures

- "MONTANT GPLC 2012": annual amount of LPG (tank) expenditures

- "MONTANT CHARBON 2012": annual amount of coal expenditures

— "MONTANT BOIS 2012": annual amount of wood expenditures

- "MONTANT GPLB 2012": annual amount of LPG (bottle) expenditures

— "MONTANT PK 2012": annual amount of odourless kerosene or paraffin expenditures

- Variables used to calculate the equivalised net income:

— "REVENU DISPONIBLE 2012": disposal income

- "EPMDR2": amount of mortgage taken out to pay for the purchase of the dwelling (for homeowners)

- "EFAMR": amount of financial support (for homeowners - to be included when calculating housing costs)

— "ELLD": rent (for tenants)

— "ELAMR": amount of financial support (for tenants - to be included when calculating housing costs)

- "UC": number of household consumption units

— "EHST": the surface area of the dwelling.

- Variables used to detect subjective thermal discomfort (feeling cold) at home indoors and the reason for the inability to heat dwelling to a suitable level of warmth:

- "EGCHAUF: Did you suffer from the cold for at least 24 hours in your home last winter?"?

- "ETDIFF: Have you encountered financial difficulties in paying your energy bills during the pas two years?".

Given this list of variables, we present below how we identified fuel-poor households with each indicator. Our initial data set was composed of 5405 households.

\section{B.1 Determination of fuel-poor households according to the $10 \%$ indi- cator}

Based on Section 2, we calculated the $10 \%$ indicator, I, using the following formula:

$$
\mathrm{I}=\frac{(\text { Actual) Fuel costs }}{\text { Equalised disposable income (before housing costs) }}
$$


- if $\mathrm{I} \geqslant 10 \% \Rightarrow$ the household is fuel-poor.

- if $\mathrm{I}<10 \% \Rightarrow$ the household is not fuel-poor.

742

\section{B.2 Determination of fuel-poor households according to the LIHC indi- cator}

Based on Section 2, we calculated the LIHC indicator according the following formula:

$\left\{\begin{array}{l}\text { Equalised net income } \leqslant 60 \% \text { (Equalised median net income) } \\ \text { Equalised fuel expenditures } \geqslant \text { Required national median fuel expenditures }\end{array}\right.$

Table B.1 - Threshold of the third decile of income $(c u)$

\begin{tabular}{lll}
\hline Year & "Phébus" threshold & National threshold $\left.{ }^{a}\right]$ \\
\hline 2011 & - & $€ 16920$ \\
2012 & $€ 16235.20$ & $€ 16850$ \\
2013 & - & $€ 16930$ \\
\hline
\end{tabular}

a. We note that these thresholds do not represent the exact value of national threshold of the third decile of income (cu) but rather the standard of living of population having an income level situated between the national third and fourth deciles of income.

$$
\frac{(\text { Actual) Fuel costs }}{\text { Equalised disposable income }} \geqslant 10 \%
$$

$$
\begin{aligned}
\text { Equalised disposable income }(c u) & =\frac{\text { Disposable income }}{\text { Number of consumption unities }} \\
& <\text { Threshold of the third decile of income }
\end{aligned}
$$

51. https://www.insee.fr/fr/statistiques/2417897 Accessed in July 20, 2017. 

Equalised net income is calculated as follows:

Equalised net income $(c u)=\frac{\text { Disposable income - Housing costs - Domestic fuel costs }}{\text { Number of consumption units }}$

794

Equalised fuel expenditures are calculated by dividing fuel expenditures by the number of consumption units in the case of the LIHC $(c u)$ indicator and by the surface area of the dwelling in the case of the LIHC $\left(m^{2}\right)$ indicator:

- LIHC $(c u)$ indicator:

$$
\text { Equalised fuel expenditures }(c u)=\frac{\text { Fuel expenditures }}{\text { Number of consumption units }}
$$

- LIHC $\left(m^{2}\right)$ indicator:

$$
\text { Equalised fuel expenditures }\left(m^{2}\right)=\frac{\text { Fuel expenditures }}{\text { Surface }}
$$

In our sample, the value of $60 \%$ of equivalised median net income is equal to $€ 12,151.2$ and values of the equivalised median fuel expenditures in the case of LIHC $(c u)$ and LIHC $\left(m^{2}\right)$ are respectively equal to $€ 841$ and $€ 14.64$.

Our results show that $10.95 \%$ of households in our initial sample are fuel-poor according the LIHC $\left(m^{2}\right)$ indicator, i.e. 592 of 5405 households and $9.52 \%$ according to the LIHC $(c u)$ indicator, i.e. 514 of 5405 households.

\section{B.3 Determination of fuel-poor households according to the Thermal Discomfort indicator}

Following the approach of ONPE (2016), a household is fuel-poor according to this subjective indicator if it satisfies two conditions:

- Condition 1: a household declares feeling cold because of at least one of the first five reasons which are considered to be the most representative of a fuel poverty situation, namely:

1. Insufficient heating system,

2. Breakdown of heating system,

3. Poor insulation,

4. Household heating restriction due to financial burden,

5. Energy supply cut-off due to unpaid bills,

6. Improper adjustment or late start-up of the heating system,

7. Other reasons.

- Condition 2: a household has an income level less than or equal to the third decile.

Depending on data available in "Phébus", we consider that a household is fuel-poor if it answers

"Yes" to the following two questions related to Condition 1:

— "Did you suffer from the cold for at least 24 hours in your home last winter?" 
796 - "Have you encountered financial difficulties in paying your energy bills?".

797

${ }_{798}$ After that, to satisfy Condition 2, we selected only those households having an income level less 799 than or equal to the third decile.

soo Our calculations show that $7.75 \%$, thus, 419 of the initial 5045 households are fuel-poor. 


\section{Potential drivers of fuel poverty: summary of the litera-} ture

Table C.1 - Potential drivers of fuel poverty: summary of the literature. Based on Bennett et al. (2002), Scott et al. (2008), Healy (2003), Healy and Clinch (2004), Palmer et al. (2008), Fahmy et al. (2011), Nicolas et al. (2012), Thomson and Snell (2013), Mayer et al. (2014), Waddams Price et al. (2012), Legendre and Ricci (2015), Charlier et al. (2015), Roberts et al. (2015), Fabbri (2015), Ambrosio et al. (2015), and Hache et al. (2017).

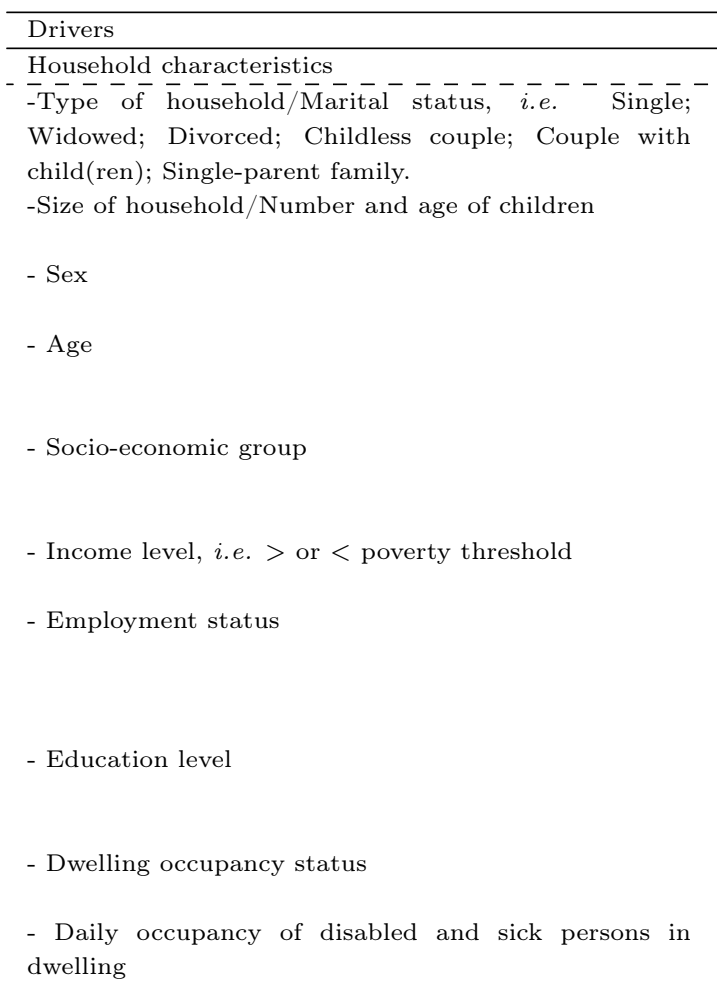

Expected effect

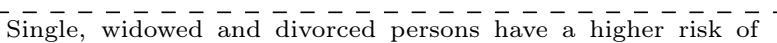
being fuel-poor.

The presence of children increases energy needs, thus, the probability of falling into fuel poverty.

Women, mainly single, with dependent children, and unemployed are usually fuel-poor.

Elderly people seem to be more vulnerable (higher energy needs) and more likely to fall into fuel poverty due to lower incomes.

Belonging to a high socio-economic group reduces the risk of being fuel-poor because it increases the probability of having a high income level.

A high income level reduces the risk of being fuel vulnerable because its ensures the ability to afford energy 52

Employment ensures income, thus the ability to afford energy and reduces the risk of falling into fuel poverty. Conversely, students, unemployed workers and retirees have lower income thus higher likelihood of falling into fuel poverty.

High educational level reduces the risk of being a fuel-poor because it increases the probability of being employed and having a high income.

Homeowners are less frequently fuel-poor, likely because they have higher income and ensure energy efficiency of their home. Disabled and sick persons have higher probability of being fuelpoor due to more time spent at home, and thereby higher energy needs.

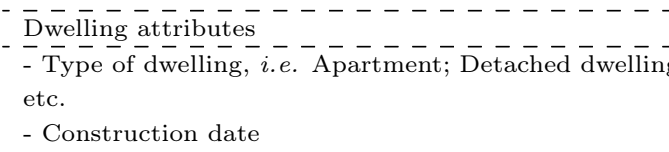

The fuel poverty risk increases when the household is $\overline{\text { living in }}$ a detached dwelling.

In France, the first regulations on thermal efficiency came into effect in 1974. Dwellings built after this date are more energy efficient, which may decrease the fuel poverty risk for people living in them.

- Housing surface

Living in a large dwelling increases the probability of becoming fuel-poor because energy needs are higher.

- Heating system

- Heating energy source

- Inefficiency of lighting and others electric appliances Individual boiler, wood stove or coal stove are usually associated with a high probability of being fuel-poor.

High energy prices increase the risk of being fuel-poor.

Lighting and other electric appliances account for an increasing share of residential energy consumption (10-20\%), thus the multiplication and poor energy efficiency of these appliances can lead to high energy needs.

- Energy efficiency

Living in an energy inefficient dwelling increases the consumption of energy and thereby the probability of falling into fuel poverty.

- Other dwelling attributes, i.e. Dampness, leaks, ven-

The presence of dampness, leaks or a broken ventilation system tilation system, poor lighting, etc.

52. Regardless the objective income level, there is a subjective dimension in the household's own perception of its financial endowment and quality of life. This perception can affect the amount it decides to devote to satisfy its energy needs. 
Table C.1 - Continued

\begin{tabular}{ll}
\hline Drivers & Expected effect \\
\hline - Type of energy payments, i.e. Standard payment ver- & $\begin{array}{l}\text { People paying with pre-payment meters are charged a higher } \\
\text { price of energy, thereby increasing the risk of falling into fuel } \\
\text { poverty. }\end{array}$ \\
& $\begin{array}{l}\text { Living in a hot region decreases heating needs and, therefore, } \\
\text { the risk of being fuel-poor } 53\end{array}$ \\
- Climate characteristics, i.e. Mediterranean; Conti- & Owning a vehicle increases the probability of being fuel-poor \\
nental; Oceanic; Temperate. & because of commute expenditures. \\
- Vehicle ownership & $\begin{array}{l}\text { It seems that people living in rural areas have a higher risk of } \\
\text { falling into fuel poverty because they do not have good access } \\
\text { - Geographic location/ rural/ low urbanisation level }\end{array}$ \\
& $\begin{array}{l}\text { to cheap energy sources (natural gas) or competitive markets. } \\
\text { and diversified. }\end{array}$ \\
\hline
\end{tabular}

53. Conversely, we note that energy needs can be high in a hot region due to the use of an air-conditioning system (cf. Fouquau and Bessec (2008)). 
${ }_{803}$ D Complementary figures for the intra-indicator analysis (section 3.2

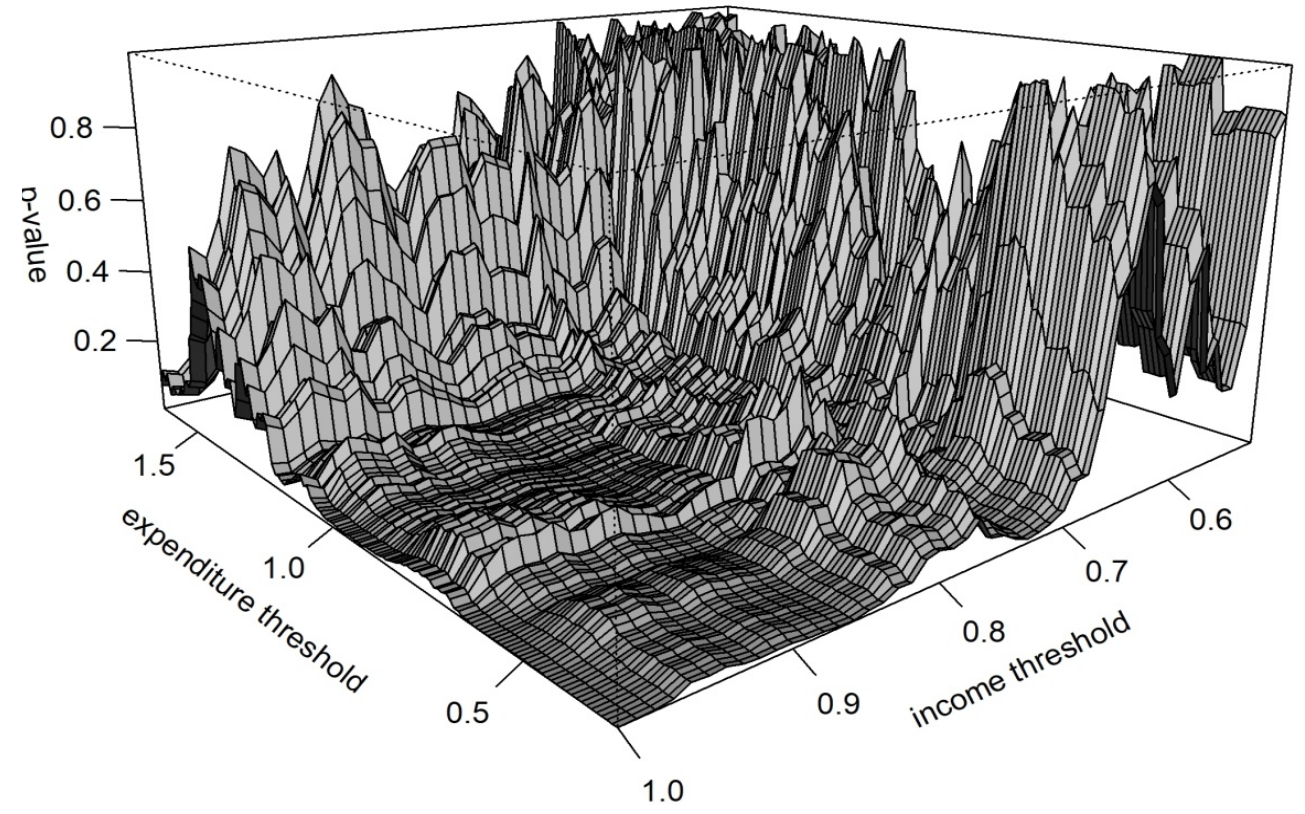

(a)

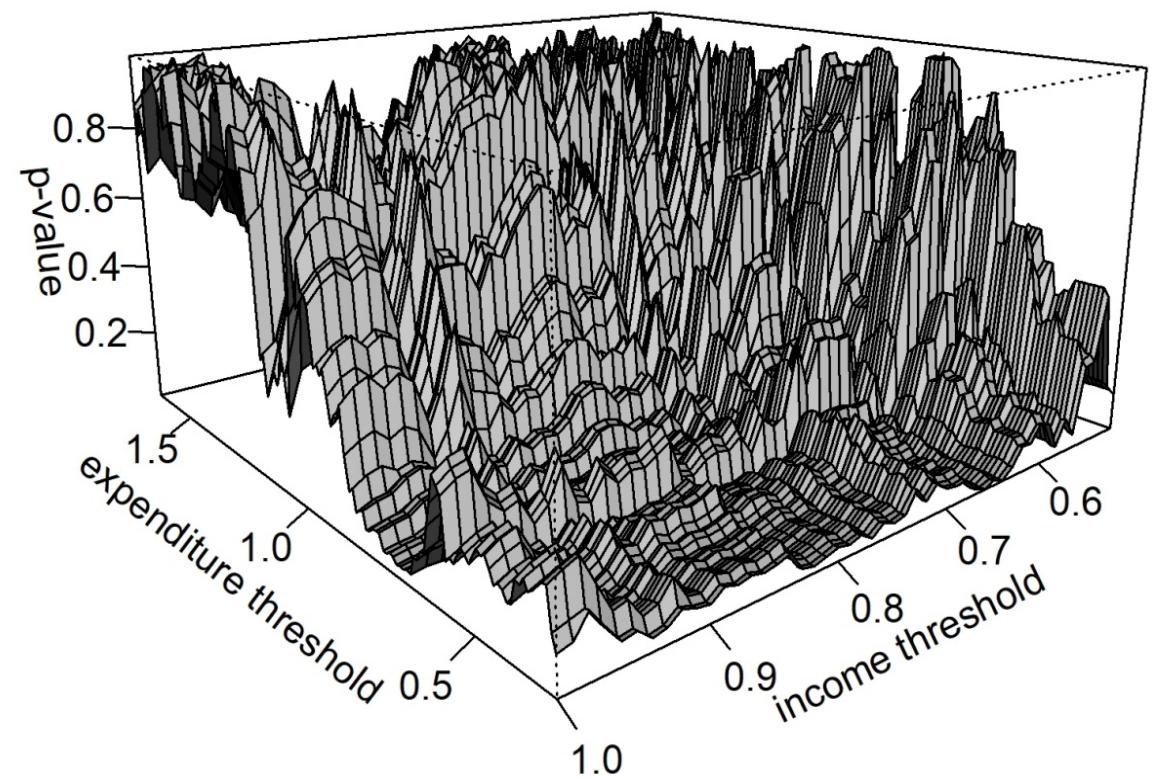

(b)

Figure D.1. (a) A Statistical significance of the variable "Isolated elderly people" in the model according to different values of the two thresholds of the LIHC $\left(\mathrm{m}^{2}\right)$ indicator, (b) B Statistical significance of the variable "Isolated women" in the model according to different values of the two thresholds of the LIHC $\left(\mathrm{m}^{2}\right)$ indicator. 
G. Ambrosio, F. Belaid, S. Bair, and O. Teissier. Analyse de la précarité énergétique à la lumière de l'enquête PHÉBUS, 2015. Observatoire national de la précarité énergétique. Centre scientifique et technique du bâtiment.

M. Bennett, D. Cooke, and C. Waddams Price. Left out in the cold? New energy tariffs, low-income households and the fuel poor. Fiscal Studies, 23, 2002.

A. Blavier, F. Dimitropoulos, B. Faraco, and M. Moisan. Précarité energétique: état des lieux et propositions d'actions, 2011. URL http://www.precarite-energie.org/IMG/ pdf/Precarite_energetique_-_tables_rondes_departementales_V2-2.pdf_[Accessed_ December_08,_2016]. Réseau d'Acteurs Précarité-Énergie-Logement (RAPPEL).

B. Boardman. Fuel poverty: from cold homes to affordable warmth, 1991. London: Belhaven Press. ISBN: 1852931396, 978-1852931391. 224 p.

B. Boardman. Fuel poverty synthesis: Lessons learnt, actions needed. Energy Policy, 49, 2012.

T. Callan, B. Nolan, and C. T. Whelan. Resources, deprivation and the measurement of poverty. Journal of Social Policy, 22(2):141-172, 1993.

D. Charlier. La rénovation énergétique en France dans le secteur résidentiel privé. Revue de l'OFCE In collection Débats et Politiques, 128:395-419, 2013.

D. Charlier. Éfficacité énergétique dans le bâtiment et paradoxe énergétique : quelles conséquences pour la transition énergétique. Revue d'Economie Industrielle, 148:229-262, 2014.

D. Charlier and B. Legendre. Fuel poverty: a composite index approach, 2016. URL a http://faere.fr/pub/PolicyPapers/Charlier_Legendre_FAERE_PP2016.06.pdf_ [Accessed_July_04,_2017]. FAERE Policy Paper, 2016-06.

D. Charlier, A. Risch, and C. Salmon. Les indicateurs de la précarité énergétique en France. Revue Française d'Economie, 4(XXX):197-230, 2015.

R. Day, G. Walker, and N. Simcock. Conceptualising energy use and energy poverty using a capabilities framework. Energy policy, 93:255-264, 2016.

DECC. The fuel poverty statistics methodology and user manual, 2014. URL https://www.gov . u uk/government/uploads/system/uploads/attachment_data/file/429774/fuel_poverty_ statistics_methodology_and_user_manual.pdf_[Accessed_November_30,_2015]. Department of Energy \& Climate Change. URN 15D/166. 57 p.

DETR. UK fuel poverty strategy, 2001. Department of the Environment, Transport and the Regions (DETR). London.

I. Devalière. Comment prévenir la précarité énergétique? Les leviers possibles et les risques inhérents à la libéralisation du service de l'énergie. Les Annales de la Recherche Urbaine, 103: 137-143, 2007.

DSDNI. Ending fuel poverty: a strategy for Northern Ireland, 2004. Department for Social Development Northern Ireland (DSDNI). Belfast.

DTI. Meeting the energy challenge: a white paper on energy. The stationary office, London, 2007. Department for Trade and Industry (DTI). 
U. Dubois. From targeting to implementation: the role of identification of fuel poor households. Energy policy, 49:107-115, 2012.

N. Dutreix, C. Baecher, B. Pianu, and E. Collomb. Figure(s) de la précarité énergén tique, 2014. URL http://www.urbanisme-puca.gouv.fr/IMG/pdf/figures-precariteenergetique.pdf_[Accessed_November_30,_2016]. Une synthèse réalisée par Nomadéis. Synthèse réalisée entre septembre 2013 et mars 2014 à la demande du Plan Urbanisme Construction et Architecture (PUCA).

EPEE. Diagnosis of causes and consequences of fuel poverty in Belgium, France, Italy, Spain and United Kingdom, 2006. URL http://www.powerhouseeurope.eu/uploads/tx_ phecasestudies/Analysis_report_epee_3_2_EN.pdf_[Accessed_November_27,_2015]. European Fuel Poverty and Energy Efficiency (EPEE) project, EIE/06/158/SI2.447367, WP2 Deliverable 5, 69 p.

K. Fabbri. Building and fuel poverty, an index to measure fuel poverty: an Italian case study. Energy, 89:244-258, 2015.

E. Fahmy, D. Gordon, and D. Patsios. Predicting fuel poverty at a small-area level in England. Energy policy, 39:4370-4377, 2011.

J. Fouquau and M. Bessec. The non-linear link between electricity consumption and temperature in Europe : a threshold panel approach. Energy Economics, 30:2705-2721, 2008.

D. Gordon, L. Adelman, K. Ashworth, J. Bradshaw, R. Levitas, S. Middleton, C. Pantazis, D. Pastios, S. Payne, P. Townsend, and J. Williams. Poverty and social exclusion in Britain, 2000. Joseph Rowntree Foundation, York.

E. Hache, D. Leboullenger, and V. Mignon. Beyond average energy consumption in the French residential housing market: A household classification approach. Energy Policy, 107, 2017.

J. Healy. Fuel poverty and policy in Ireland and the European Union, 2003. URL https://www.tcd.ie/policy-institute/assets/pdf/BP12_Healy_Fuel.pdf_[Accessed_ February_20,_2016]. Studies in public policy. Policy Institute at Trinity College Dublin in association with Combat Poverty agency. ISBN 1-902585-10-0.

J. D. Healy and J. P. Clinch. Fuel poverty in Europe : a cross country analysis using new composite measurement, 2002. URL https://www.ucd.ie/gpep/research/archivedworkingpapers/ 2002/02-04.pdf_[Accessed_March_27,_2016]. Environmental studies research series working papers 02/04. ISSN 1393-9335. Department of environmental studies University College. Dublin Richview, Dublin - Ireland.

J. D. Healy and J. P. Clinch. Quantifying the severity of fuel poverty, its relationship with poor housing and reasons for non-investment in energy-saving measures in Ireland. Energy Policy, 32 : 207-220, 2004.

P. Heindl. Measuring fuel poverty general consideration and application to German household data, 2013. Discussion Paper No. 13-046. Centre for European Economic Research. 32 p.

P. Heindl and R. Schuessler. Dynamic properties of energy affordability measures. Energy Policy, $86,2015$. 
J. Hills. Fuel poverty: the problem and its measurement. Interim report of the of the fuel poverty review, 2011. URL http://sticerd.1se.ac.uk/dps/case/cr/CASEreport69.pdf_[Accessed_ January_27,_2016]. Center of analysis of social exclusion. Report 69. ISSN 1465-3001.

J. Hills. Getting the measure of fuel poverty. Final report of the fuel poverty review, 2012. URL http://sticerd.lse.ac.uk/dps/case/cr/CASEreport72.pdf_[Accessed_March_ 27,_2016]. Center of analysis of social exclusion. Report 72. ISSN 1465-3001.

S. Host, D. Grange, L. Mettetal, , and U. Dubois. Précarité énergétique et santé : état des connaissances et situation en Ile-de-France. Pollution atmosphérique [En ligne], 223, mis à jour le : 09/01/2015, 2014. URL http://lodel.irevues.inist.fr/pollution-atmospherique/ index.php?id=4580_[Accessed_April_30,_2016]

F. Husson, S. Lê, and J. Pagès. Analyse de données avec R. Bruxelles et Paris, Second edition, 2016. Presses Universitaires de Rennes (PUR). ISBN 978-2-7535-4869-5.

INSEE ENL. Enquête logement en 2006, 2006. URL http://www.insee.fr/fr/methodes/ default.asp?page=sources/ope-enq-logement.htm_[Accessed_April_07,_2016] Organisme responsable : INSEE, Direction des Statistiques Démographiques et Sociales (DSDS).

B. C. Isherwood and R. M. Hancock. Household expenditure on fuel: Distributional aspects, 1979. Economic Adviser?s Office, DHSS, London.

JORF. Loi n 90-449 du 31 mai 1990 visant à la mise en oeuvre du droit au lo1 gement (1), 1990. URL http://www.legifrance.gouv.fr/affichTexte.do?cidTexte= LEGITEXT000006075926_[Accessed_December_10,_2015]. NOR: EQUX8900132L. Version consolidée au 10 décembre 2015.

JORF. Arrêté du 15 septembre 2006 relatif au diagnostic de performance énergétique pour les bâtiments existants proposés à la vente en France métropolitaine, 2006. URL http://www.legifrance.gouv.fr/affichTexte.do?cidTexte=JORFTEXT000000788395f _ [Accessed_December_03,_2015]. NOR: SOCU0611881A Version consolidée au 03 décembre 2015.

B. Legendre and O. Ricci. Measuring fuel poverty in France: which households are the most fuel vulnerable? Energy economics, 49:620-628, 2015.

C. Liddell, S. J. P. Morris, C.and McKenzie, and G. Rae. Measuring and monitoring fuel poverty in the uk: National and regional perspectives. Energy Policy, 38, 2012.

I. Mayer, E. Nimal, P. Nogue, and M. Sevenet. The two faces of energy poverty: a case study of households? Energy burden in the residential and mobility sectors at the city level. Transportation Research Procedia, 4, 2014.

R. Moore. Definitions of fuel poverty: implications for policy. Energy policy, 49:19-26, 2012.

J. P. Nicolas, F. Vanco, and D. Verry. Mobilité quotidienne et vulnérabilité des ménages. Revue d?économie régionale et urbaine, 1, 2012.

P. Nussbaumer, M. Bazilian, and V. Modi. Capabilities as fundamental entitlements: Sen and global justice. Feminist economics, 9(2-3):33-59, 2003.

P. Nussbaumer, M. Bazilian, and V. Modi. Measuring energy poverty: focusing on what matters. Renewable sustainable energy review, 16:231-243, 2012. 
S. Okushima. Gauging energy poverty: A multidimensional approach. Energy, Article in press: http://dx.doi.org/10.1016/ j.energy.2017.05.137, 2017.

ONPE. Définitions, indicateurs, premiers résultats et recommandations, 2014. URL http://www . presse. ademe.fr/wp-content/uploads/2014/10/ONPE1erRapportSynthèse. pdf_[Accessed_December_3,_2015]. Premier rapport de l'ONPE (Observatoire National de la Précarité Énergétique).

ONPE. Les chiffres clés de la précarité énergétique, 2015. URL http://www.onpe.org/ sites/default/files/pdf/tableau_de_bord/chiffres_cles.pdf_[Accessed_November_ 27,_2015]. Observatoire National de la Précarité Énergétique (ONPE). Édition numéro 1.

ONPE. Les chiffres clés de la précarité énergétique, 2016. URL/http://onpe.org/sites/default/ files/pdf/tableau_de_bord/chiffres-cles-precarite-energetique-novembre2016.pdf_ [Accessed_January_27,_2017]. Observatoire National de la Précarité Énergétique (ONPE). Édition numéro 2.

G. Palmer, T. MacInnes, and P. Kenway. Cold and poor: an analysis of the link between fuel 1. poverty and low income, 2008. URL http://www.poverty.org.uk/reports/fuel\%20poverty. pdf_[Accessed_December_08,_2015]. Published by New Policy Institute, 3 Coppergate House, 16 Brune Street London E1 7NJ. ISBN: 978-1-902080-24-6.

L. Papada and D. Kaliampakos. Measuring energy poverty in Greece. Energy Policy, 94, 2016.

E. Phimister, E. Vera-Toscano, and D. Roberts. The dynamics of energy poverty: Evidence from Spain. Economics of Energy \& Environmental Policy, 4(1):153-166, 2015.

C. W. Price, K. Brazier, and W. Wang. Objective and subjective measures of fuel poverty. Energy Policy, 49:33-39, 2012.

D. Roberts, E. Vera-Toscano, and E. Phimister. Fuel poverty in the UK: is there a difference between rural and urban areas? Energy Policy, 87, 2015.

S. Scott, S. Lyons, C. Keane, D. McCarthy, , and R. S. J. Tol. Fuel poverty in Irland: extend, affected groups and policy issues, 2008. URL https://www.esri.ie/pubs/WP262.pdf_ [Accessed_November_27,_2016]. ESRI, Working Paper No. 262, 73 p.

Scottish Executive. The Scottish fuel poverty statement, 2002. Scottish Executive, Edinburgh.

A. Sen. Inequality reexamined, 1992. Clarendon Press. ISBN: 0198283342. 224 p.

M. Smith and C. Seward. The relational ontology of Amartya Sen's capability approach: incorporating social and individual causes. Journal of Humain development capabilities, 10, 2009.

H. Thomson and C. Snell. Quantifying the prevalence of fuel poverty across the European Union. Energy Policy, 52:563-572, 2013.

P. Townsend. Poverty in the United Kingdom, 1979. Penguin Books, London.

C. Waddams Price, K. Brazier, and W. Wang. Objective and subjective measures of fuel poverty. Energy Policy, 49:33-39, 2012.

WAG. Warm homes and energy conservation act 2000: a fuel poverty commitment for Wales, 2003. Welsh Assembly Government (WAG), Cardiff.

D. Ürge Vorsatz and D. Tirado Herrero. Building synergies between climate change mitigation and energy poverty alleviation. Energy Policy, 49:83-90, 2012. 